\section{Pacific Northwest}

National Laboratory

Operated by Battelle for the

U.S. Department of Energy

\title{
The Russian Federation's Ministry of Atomic Energy: Programs and Developments
}

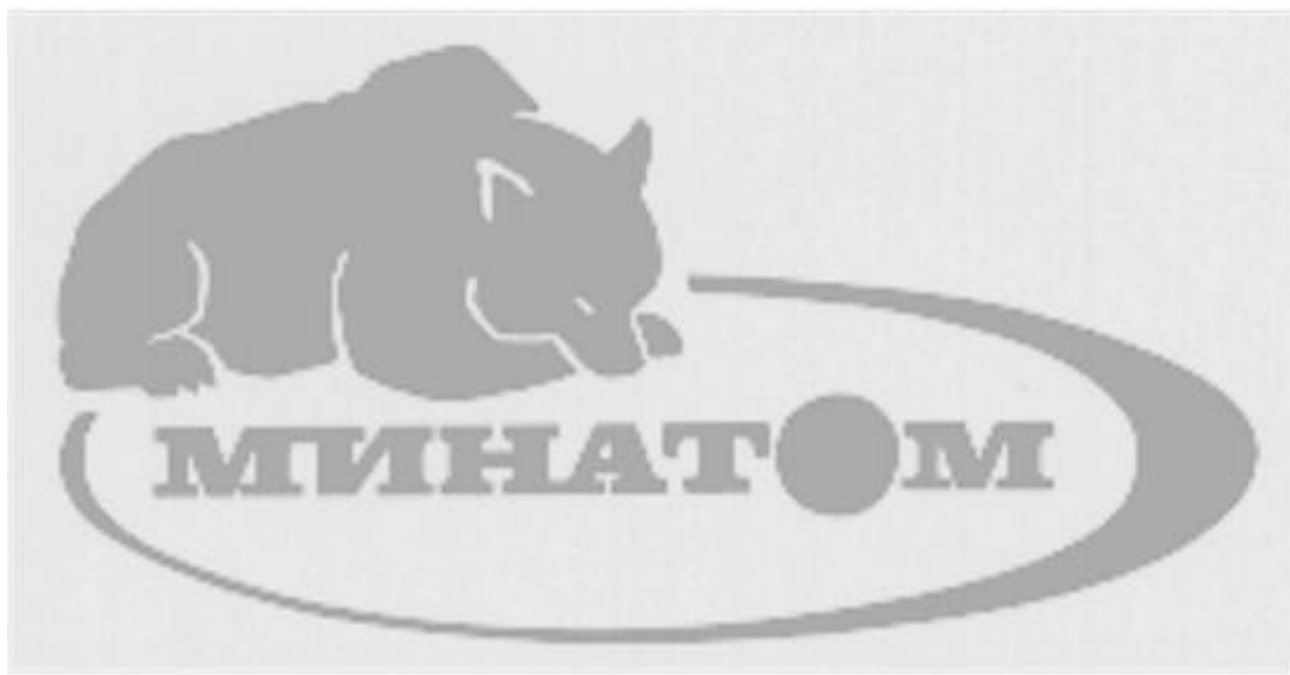

C. M. Johnson

February 2000

Prepared for the U.S. D epartment of Energy under Contract DE-AC06-76RLO 1830 


\section{DISCLAIMER}

This report was prepared as an account of work sponsored by an agency of the United States Government. Neither the United States Government nor any agency thereof, nor Battelle Memorial Institute, nor any of their employees, makes any warranty, express or implied or assumes any legal liability or responsibility for the accuracy, completeness or usefulness of any information, apparatus, product or process disclosed, or represents that its use would no infringe privately owned rights. Reference herein to any specific commercial product, process, or service by trade name, trademark, manufacturer, or otherwise does not necessarily constitute or imply its endorsement, recommendation, or favoring by the United States Government or any agency thereof, or Battelle Memorial Institute. The views and opinions of authors expressed herein do not necessarily state or reflect those of the United States Government or any agency thereof.

\section{PACIFIC NORTHWEST NATIONAL LABORATORY operated by \\ BATTELLE for the \\ UNITED STATES DEPARTMENT OF ENERGY Under Contract DE-AC06-76RLO 1830}


PNNL-13197

\section{The Russian Federation's Ministry of Atomic Energy: Programs and Developments}

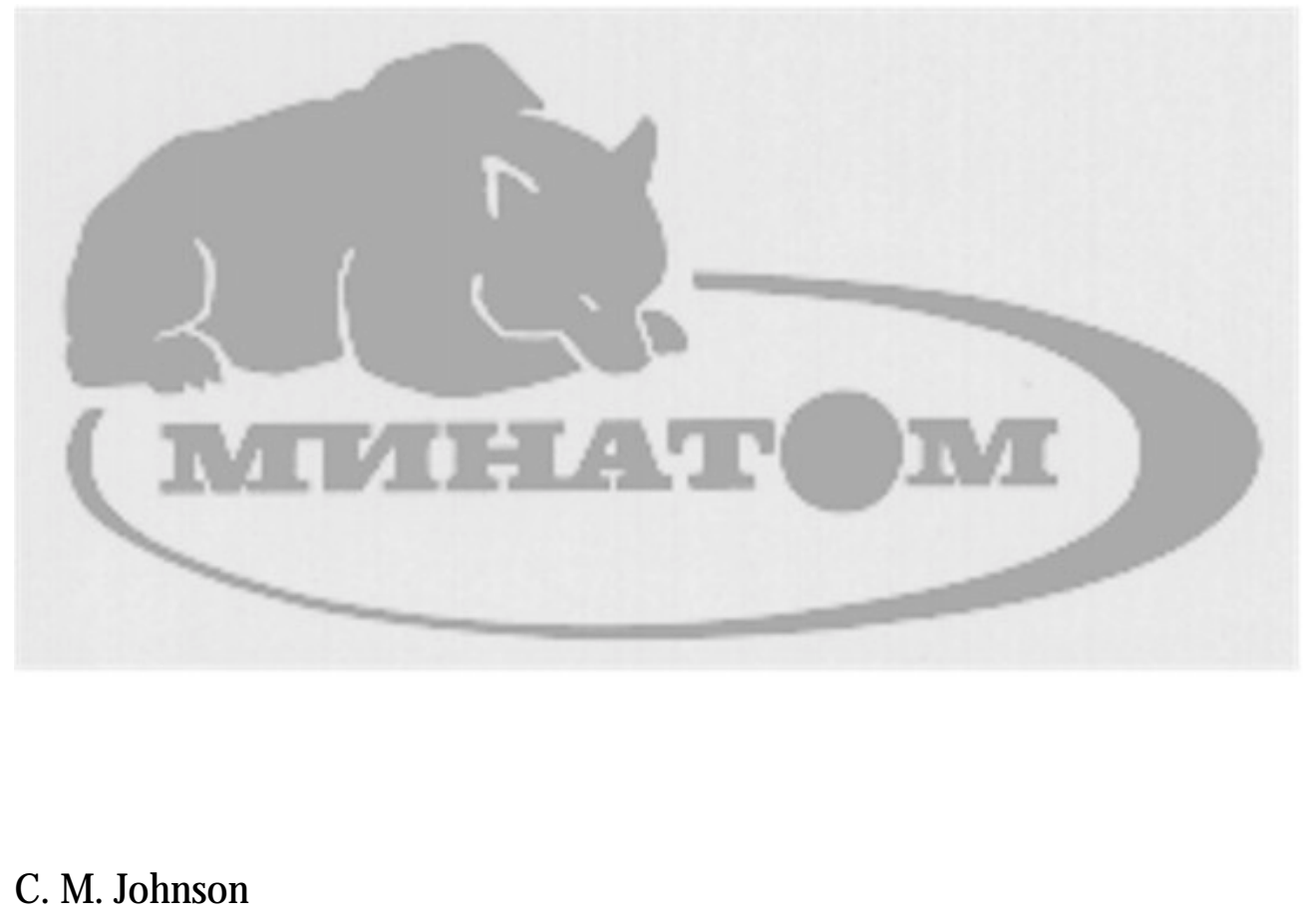

February 2000

Prepared for the U.S. D epartment of Energy under Contract D E-AC06-76RLO 1830 


\section{Summary of Findings}

This paper reviews select programs driving the Ministry of Atomic Energy of the Russian Federation's (Minatom) efforts to raise funds, comments on their potential viability, and highlights areas likely to be of particular concern for the United States over the next three to five years. Listed below are this paper's findings.

- Despite numerous cabinet displacements throughout the Yeltsin administration, Yevgeny Adamov was reappointed Minister on four occasions. With Boris Yeltsin's January 1, 2000 resignation, Adamov's long-term position as the head of the Ministry is more tenuous, but he will likely retain his position until at least the March 2000 elections. Acting President Vladimir Putin is unlikely to reorganize his cabinet prior to that date and there are no signs that Putin is dissatisfied with Adamov's leadership of Minatom.

- Adamov's chief priorities are downsizing Minatom's defense sector, increasing the oversight of subsidiary bodies by the central bureaucracy and consolidating commercial elements of the Ministry within an umbrella organization called "Atomprom."

- Viktor Mikhaylov, Adamov's predecessor and critic of his reform efforts, has been "relieved of his duties as First Deputy Minister." While he retains his positions as Chief of the Science Councils and Chief Scientist at Arzamas-16, his influence on Minatom's direction is greatly diminished. Adamov will likely continue his efforts to further marginalize Mikhaylov in the coming year.

- Securing extra-budgetary sources of income continues to be the major factor guiding Minatom's international business dealings. The Ministry will continue to aggressively promote the sale of nuclear technology abroad, often to countries with questionable nonproliferation commitments.

- Given the financial difficulties in Russia and Minatom's client states, however, few nuclear development programs will come to fruition for a number of years, if ever. Nevertheless, certain "peaceful nuclear cooperation agreements" should be carefully monitored - particularly those negotiated with Cuba, Iran, Libya and Syria.

- Waste management has also risen in importance for Minatom. Opportunities for raising funds by reprocessing, storing and permanently disposing of spent fuel from foreign states are being explored. Although currently prohibited by federal law, the Russian Parliament will likely pass legislation in support of this program. 


\section{Contents}

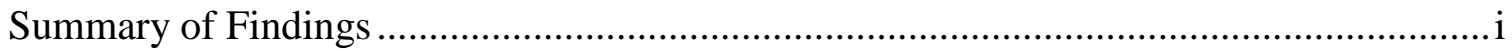

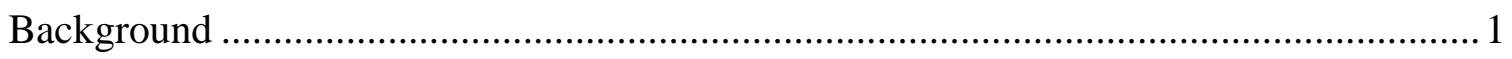

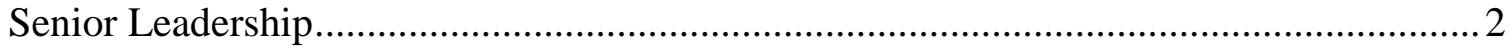

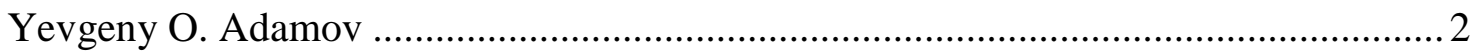

Political Supporters/Detractors .................................................................. 3

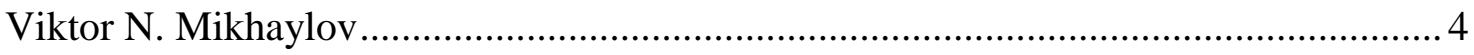

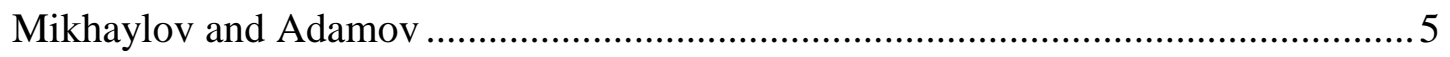

The August 1998 Financial Meltdown.................................................................. 7

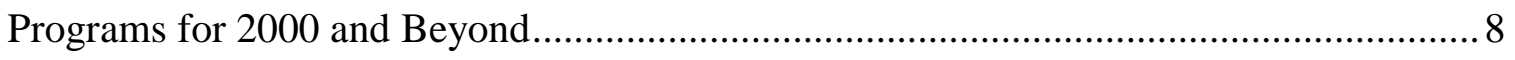

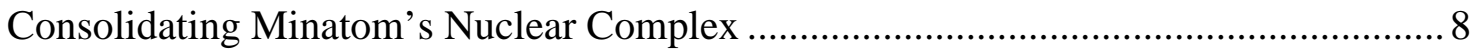

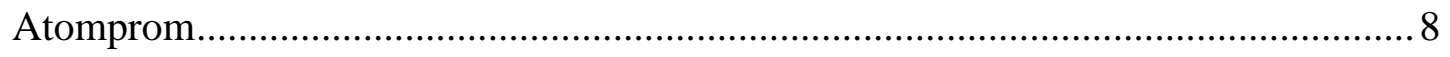

Tightening Central Control Over Subsidiary Agencies....................................... 9

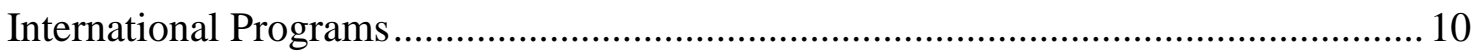

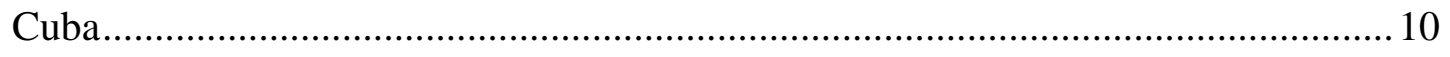

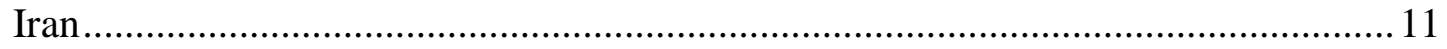

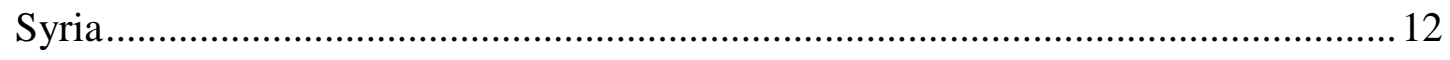

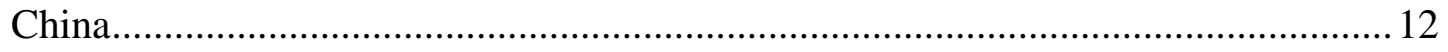

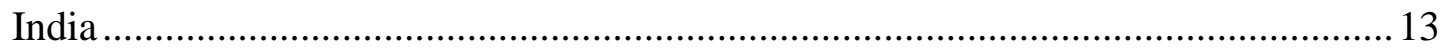

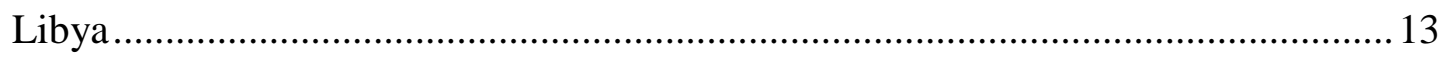

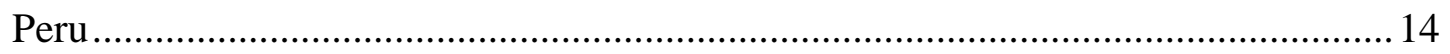

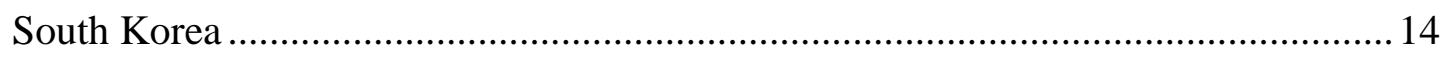


Other International Projects

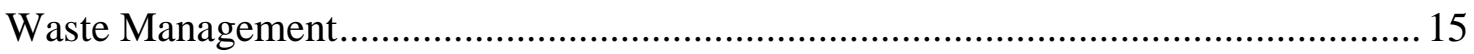

Importing Spent Fuel for Reprocessing and Permanent Disposition ....................... 16

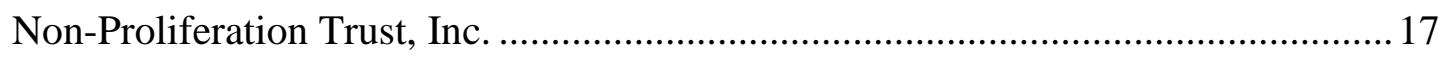

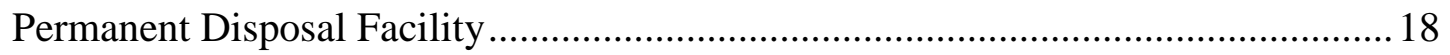

Submarine Decommissioning and Control of Radons ........................................ 19

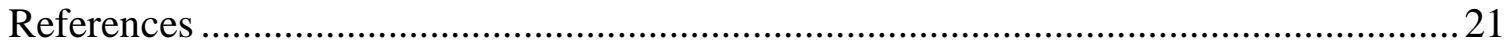

Directors of Minatom and Predecessor Institutions ..............................................A-1

Directors of Minatom and Predecessor Institutions ............................................ B-1

The Russian Federation of Atomic Energy …..................................................... 


\section{Background}

The Ministry of Atomic Energy of the Russian Federation (Minatom) is one of Russia's largest and most influential federal bodies. Within the organization

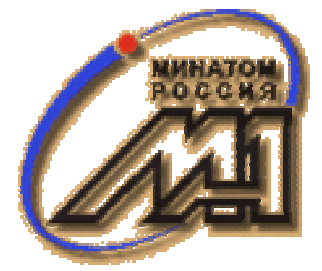
are over 150 subsidiary agencies employing 556,000 scientists and engineers with an estimated budget of $\$ 3$ billion per year.

The Ministry oversees all aspects of Russia's nuclear complex from designing, building, maintaining and dismantling nuclear warheads to energy generation and reactor construction. Minatom is responsible for the production of fissile materials and fabrication of reactor fuel for power generation and naval propulsion. It conducts basic scientific research and development, oversees the ten closed "nuclear cities" and manages radioactive waste.

Minatom's institutional origins date to 1945 with the Special Committee of the Soviet Union's State Committee on Defense and the First Main Directorate (PGU) of the Soviet Council of Ministers. The Defense Committee, established on August 20, 1945, was the leading body on nuclear issues and the PGU, created ten days later, was the interdepartmental organization charged with coordinating the development of nuclear weapons.

These two institutions functioned until 1953 when the PGU was reorganized as the Ministry of Medium Machine Building (MMBM, USSR Minsredmash). The MMBM was primarily concerned with nuclear weapons while the Russian Academy of Sciences and independent laboratories handled energy issues. In 1989 MMBM combined with the Ministry of Nuclear Power, which was created after the Chernobyl disaster, to form the Ministry of Atomic Power and Industry (MAPI). With MAPI, the entire nuclear complex was united under one organization. MAPI operated until the breakup of the Soviet Union and was replaced by the new Ministry of Atomic Energy on January 21, 1992. 


\section{Senior Leadership}

\section{Yevgeny O. Adamov}

In March 1998 an unexpected change occurred in the senior leadership of Minatom. Yevgeny Adamov, the Director of the Research and Development Institute for Power Engineering (NIKIET or ENTEK), replaced Victor N. Mikhaylov, who had overseen the organization since its creation in 1992. Directors of Minatom and its predecessor organizations had always come from the weapons complex. Adamov's appointment, with his background in nuclear power engineering, was a move to orient the Ministry away from defense orders towards the promotion of civilian programs and activities for commercial export.

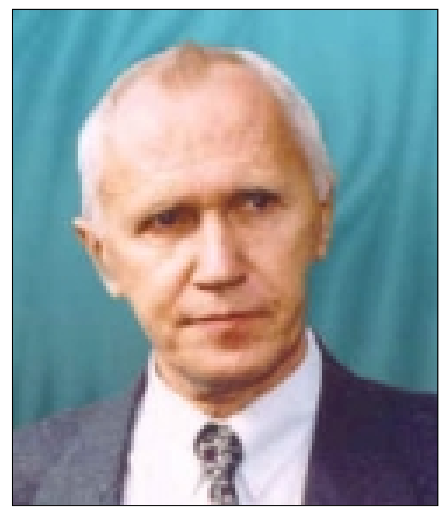
Name:
Yevgeny Olegovich Adamov
Position:
Minister of Minatom
Yevgeny Adamov was born April 28, 1939 in Moscow. He graduated from the Moscow Aviation Institute in 1962 and worked for the Institute for three years. In 1965 Adamov was assigned to the Kurchatov Institute as an engineer, eventually rising to the level of Deputy Director. In 1986 he received a Doctor of Science (Technology) and was promoted to Director of the Research and Development Institute of Power Engineering (NIKIET). On March 4, 1998, Adamov was named Minister of Minatom.

Since taking the helm, Adamov has been a vocal advocate of reforming, downsizing and modernizing the Ministry. Although he supports the maintenance of a vibrant weapons complex, he believes the long-term financial health of the Ministry rests with commercial power and nuclear exports. ${ }^{1}$

To increase the Ministry's commercial competitiveness, Adamov is attempting to separate the weapons complex from civilian power divisions. This change is a significant departure from Minatom's past. Unlike the United States, Russia has never distinguished civilian from military applications of nuclear energy - it was all considered defense related. The fusion of the defense and civilian sectors, however, has inhibited the Ministry from exploiting commercial capabilities. Although Adamov's policies are resisted by segments of the Ministry, it appears that an equal number realize that the future survival of the Ministry depends on securing independent sources of income.

Adamov's efforts to reform the Ministry are evident in his strong support for the Nuclear Cities Initiative and Initiatives for Proliferation Prevention-U.S. Department of Energy programs to downsize the weapons complex and enhance commercial opportunities.

\footnotetext{
${ }^{1}$ See "Exclusive Interview with Russian Minister of Atomic Energy Yevgeniy Adamov," Agenstvo Politicheskikh Novostey (July 13, 1999), FBIS Document ID: FTS19990715001753 and "Interview with Yevgeniy Adamov," Nezavisimaya Gazeta (November 27, 1998), FBIS Document: FTS19981201000083.
} 
He has worked to broaden their implementation throughout the nuclear complex. Indeed, these programs are pillars in his overall strategy of downsizing the defense complex while placating weapons scientists and encouraging their transition to commercial opportunities.

Adamov is also seeking to tighten central authority over the Ministry's diverse subsidiary agencies. As discussed below, the move to tighten central authority is part of his plan to unite Minatom's commercial aspects within an umbrella organization called "Atomprom." These consolidation efforts, however, force him to walk a narrow path. An overemphasis on the civilian sector at the expense of the weapons complex risks the ire of the State Duma (lower house of parliament), which holds the legislative keys to his plans for 2000 and beyond. Yet maintenance of the defense complex at its current size is a tremendous drain on limited resources and prohibits movement toward commercial and energy development opportunities. Assuring legislators that the defense complex is strong, while simultaneously diminishing its defensive production capabilities, will remain a vexing issue for years to come.

\section{Political Supporters/Detractors}

Throughout Russia, achieving and maintaining political office depends to a significant extent on one's connections. Since Adamov became Minister, four Prime Ministers have been fired. ${ }^{2}$ After a Prime Minister is dismissed, the heads of all agencies are demoted to "Acting" status and are then either reappointed or dismissed by the new Prime Minister. Adamov, who was reappointed each time during the Yeltsin administration, has likely benefited from behind-the-scenes maneuverings of Boris Berezovskiy, a leading power broker and confidant of Boris Yeltsin. ${ }^{3}$

With Yeltsin's January 1, 2000 decision to resign the presidency, Adamov's future now largely depends on the outcome of the March elections. Vladimir Putin, who assumed the presidency after Yeltsin resigned, enjoys a favorable lead over his rivals and is favored to win. Although Putin could create a new cabinet prior to the elections, he is not expected to do so. As such, Adamov will likely remain the head of Minatom until at least March. Whether he will then remain the Minister remains to be seen. There are no signs, however, that Putin is dissatisfied with Adamov's leadership or is a political opponent of Boris Berezovskiy.

Although Adamov's alleged association with Berezovskiy probably helped him retain his position throughout the Yeltsin administration, it also earned him the distrust of many Nationalists and Communists in the Russian Duma. This distrust is not confined to representatives of extremist parties. Members of the centrist party, Yabloko, have spoken out against him as well. Adamov is repeatedly accused of being Berezovskiy's puppet

\footnotetext{
${ }^{2}$ Viktor Chernomyrdin, Sergei Kiriyenko, Yevgeny Primakov and Sergei Stepashin. Vladimir Putin assumed the presidency after Boris Yeltsin resigned on January 1, 2000.

${ }^{3}$ Adamov was appointed on March 4, 1998 and reappointed on May 8, 1998, September 30, 1998, May 25, 1999 and August 19, 1999. He has stated that he does not know Berezovskiy. See "Atomic Energy Minister Adamov Interviewed,” Agenstvo Politicheskikh (July 13, 1999), FBIS Document ID: FTS19990715001753.
} 
and of using the Ministry for personal financial gain. His emphasis on the commercial sector at the expense of the weapons complex is also decried by hard-liners as a program for unilateral disarmament. Others lambaste his participation in Nunn-Lugar nuclear security programs, going so far as to denounce him as being a spy for the United States.

Many of these charges are disseminated in journals and television programs controlled by the banking and media mogul Vladimir Gusinskiy. Besides opposing anyone aligned with Berezovskiy, Gusinskiy is disgruntled over Adamov's September 1998 decision to transfer an estimated $\$ 40$ million from his Most-Bank to Konversbank, which is controlled by Minatom. This decision, coming soon after the August 1998 economic crisis, exacerbated a financially strained situation for Most-Bank and led to sustained attacks on Adamov in Gusinskiy's publications.

Despite these persistent attacks, however, Adamov appears to have solidified his position as head of Minatom. He has replaced several Deputy Ministers, reorganized the Ministry and initiated new programs and revitalized ones that had been largely dormant under Viktor Mikhaylov.

\section{Viktor N. Mikhaylov}

Victor Mikhaylov, a self-described nuclear hawk, oversaw the Ministry from its creation in March 1992. In March 1998, to the surprise of almost everyone, he announced that he was abdicating his position to concentrate on "basic science" as First Deputy Minister for Atomic Energy and Chief of the Science Councils.

On October 25, 1999 another surprise announcement followed regarding Mikhaylov's position with Minatom. A terse release from Itar-Tass (1999) stated that then Prime Minister Vladimir Putin "[had] relieved Viktor Mikhailov... of his duties," with the disingenuous explanation that "[he had] reached a retirement age established for a state job...." This explanation is highly suspect given that other senior Minatom officials of the same age or older are not in danger of forced retirement. ${ }^{4}$ Mikhaylov's departure is therefore more likely the result of a power shift in an ongoing struggle between those promoting commercial reforms and individuals advocating a return to a more defenseorientated Ministry of Atomic Energy.

The October 1999 announcement appears to be the culmination of efforts to silence Viktor Mikhaylov's criticisms of reform efforts in Minatom. In March 1998 when Mikhaylov stepped down as Minister of Minatom, official Russian sources stated that he surrendered his position voluntarily. Yet it is more plausible that he was pressured to resign by members of President Yeltsin's inner circle. While the circumstances behind his March 1998 departure remain hidden, several indicators stand out. First, Mikhaylov

\footnotetext{
${ }^{4}$ Viktor Mikhaylov turned 65 on February 12, 1999. As a comparison, First Deputy Minister Lev Ryabev and International Relations Department Director Mikhail Ryzhov are 66 and Chief Scientist Minatom Science Council Nikolai Babaev is 68. Reaching "retirement age," therefore, does not necessitate removal from office.
} 


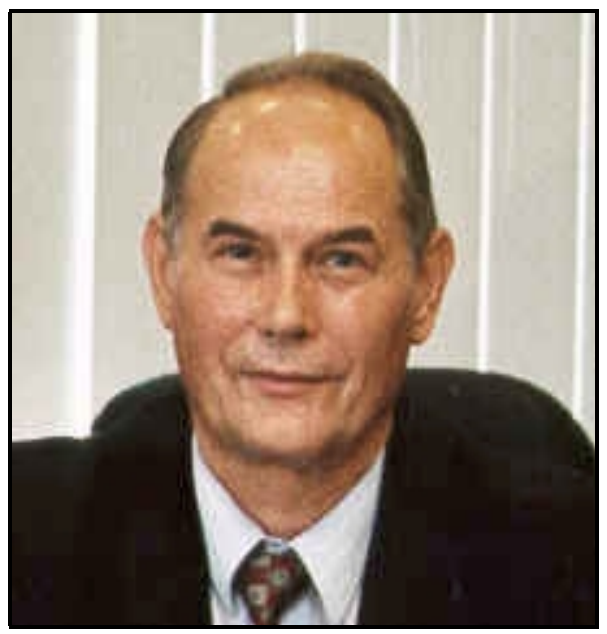

Name: $\quad$ Viktor Nikitovich Mikhaylov

Position: Head of the Science Councils, and Chief Scientist at Arzamas-16

Viktor Mikhaylov was born in Moscow on February 12, 1934. He graduated from the Moscow Physical-Engineering Institute as a specialist in theoretical and applied nuclear physics. After a number of years with Arzamas-16, he was appointed Deputy Minister in 1988 and then First Deputy Minister in 1989 of the Ministry of Medium Machine Building, a predecessor to Minatom. In March 1992 he became Minatom's first Minister and held that position until March 2, 1998. He is married, has a son and three grandsons.

resisted reforming the Ministry to reflect post-Cold War realties, which allegedly soured his relations with Anatoliy Chubays and/or Boris Nemtsov, who were at the time senior officials in Yeltsin's Government. In addition, Mikhaylov's international policies often conflicted with the Ministry of Foreign Affairs and Russia's foreign policy goals.

Charges of corruption surrounding the sale of uranium to the United States have been speculated as reasons for his departure as well. Many of these same issues are also likely behind the October 1999 decision to relieve him.

Because Mikhaylov maintained significant support in the Duma, firing him outright in 1998 was not a politically viable option. Instead, he was likely persuaded to step aside with the assurance that he would retain a senior position in the Ministry.

Such bureaucratic reshuffling has precedence for Ministers in Minatom. In the late 1980s, Mikhaylov was subordinate to Vitaly Konovalov, the head of the Ministry for Medium Machine Building, who was pressured to resign and demoted to First Deputy Minister. This then elevated Mikhaylov to Minister. ${ }^{5}$ Similarly, Lev Ryabev, currently First Deputy Minister and State Secretary, also once headed MMBM but was relegated to First Deputy Minister upon Konovalov's accession. Yet considering that Mikhaylov no longer enjoys the title of First Deputy Minister, it appears his political opponents have achieved the upper hand throughout the Ministry, Duma and Russian Government.

\section{Mikhaylov and Adamov}

In 1998 Mikhaylov reportedly handpicked Adamov to be his successor, but there is little love between the two. Adamov's vision for the Ministry is markedly different from the course plotted by his predecessor. While both agree that solvency can be best obtained through international contracts and Adamov has continued many programs initiated by Mikhaylov, they disagree on what to do with the profits. Adamov wants the earnings earmarked for commercial development, while Mikhaylov remains a vocal proponent for beefing up the defense facilities. Instead of domestic reactor construction, Mikhaylov

\footnotetext{
${ }^{5}$ Konovalov was allegedly forced to resign for not condemning the aborted 1991 coup d'etat against Mikhail Gorbachev by Communist hard-liners. He now oversees TVEL, a Minatom fuel assembly agency.
} 
stresses the need for a Russian version of "Stockpile Stewardship," the U.S. program to maintain a nuclear arsenal without explosive testing.

The political and bureaucratic maneuverings that demoted Mikhaylov to First Deputy Minister and then to the Chief of the Science Councils were likely an attempt to muzzle his opposition to reforming the Ministry, while insuring that his supporters in the Duma would not become too upset. Yet even in these positions, along with his continuing role as Chief Scientist at Arzamas-16, a role he assigned himself while Minister, Mikhaylov was able to muscle his way into participating in many defense and international development projects.

Moreover, given his forceful personality, the programs he associated with were guaranteed a high degree of media coverage. This enabled him to maintain an active voice in the Ministry and to highlight his policy preferences. Yet lacking a strong departmental backing, his influence on senior decision-makers was relatively weak. Consequently, Mikhaylov was placed in the nebulous position of being too strong to be ignored but too weak to make a difference.

Adamov surely wanted to silence Mikhaylov's criticisms, but given his support in the Duma and strong media ties, it was thought that Mikhaylov would remain a fixture of the Ministry and an annoyance to Adamov for years to come. This has changed, however, in light of the October 1999 announcement that Mikhaylov was relieved of his duties as First Deputy Minister. Indeed, his continued fall from Minister to First Deputy Minister and now to Chief of the Science Councils clearly demonstrates his diminishing influence within the Ministry. Although Mikhaylov will never be at a loss to express his opinions in Russia's media, his bureaucratic clout and ability to influence policy has greatly declined. 


\section{The August 1998 Financial Meltdown}

The August 1998 financial crisis shrank Minatom's operating budget and altered its development strategy for 1998 and beyond. Allocations from the federal budget are insufficient to sustain the Ministry's needs, and rising inflation is taking its toll. The fiscal year 1999 draft budget, for example, is reported to have covered only 45 to 50 percent of the amount necessary to maintain the Ministry's core defense programs (Khripunov 1999).

The civilian energy sector has not fared any better. Like their counterparts in the weapons complex, employees are chronically late in receiving salaries, plants are unable to collect payments from consumers and at least one reactor, Balakovo, has filed for bankruptcy. These funding shortfalls have led to allegations that reactor operators have cut corners, often in areas of nuclear safety.

The financial crisis has had three predominant affects on the Ministry's programs and policies: accelerating Adamov's drive towards consolidating the nuclear complex, pushing the Ministry to expand its international contacts and invigorating efforts to raise funds through foreign spent fuel management.

To make Minatom more efficient, Adamov is seeking to downsize the defense sector, sell off moribund facilities, strengthen the central bureaucracy's control over profitable subsidiary firms and restructure the Ministry's accounts. Developments in this area represent Adamov's most significant break from policies set by Viktor Mikhaylov, while the other two pillars of Minatom's development strategy, discussed below, deviate little from programs that have been in motion for a number of years.

International operations remain fundamental to Minatom's development strategy. By expanding its international contacts and aggressively promoting the export of nuclear technology, Minatom hopes to compensate for its budgetary shortfalls. These export activities, however, are a cause for U.S. concern since most of the states Minatom is doing business with desire weapons of mass destruction or have questionable commitments to nonproliferation. Over the past few years, Minatom has reached "cooperative nuclear agreements" with Cuba, Iran, Libya and Syria. In addition, there are ongoing projects with China and India and proposals to establish projects on the Korean Peninsula.

Minatom also hopes to raise funds by reprocessing foreign spent fuel and storing or permanently disposing of wastes from reprocessing. This plan is currently prohibited by federal legislation, but Minatom efforts to amend the law will likely succeed. To handle the potential influx of fuel, new storage and reprocessing facilities are being planned. These structures would be financed through payments for services from client states. Future profits would be then invested into other Minatom activities. States reportedly expressing an interest in this project include Switzerland, Germany, Spain, South Korea, Taiwan and possibly Japan (Greenpeace 1999). 


\section{Programs for 2000 and Beyond}

\section{Consolidating Minatom's Nuclear Complex}

Under Adamov, conversion and consolidation of the defense industry has moved to the forefront of Minatom's activities. Closing redundant facilities is viewed as a way of keeping operating budgets down and freeing scarce resources for commercial power projects and development of export opportunities.

Numerous proposals concerning how the Ministry plans to downsize the weapons complex have been aired. One of the first was an announcement that approximately 17 companies (which were not identified) would be restructured to serve the needs of the nuclear energy, machine building, medical, electronics and communications sectors with a focus on increasing their market export potential (Reuters 1999; Yadernyy Kontrol Digest 1999). Facilities that cannot be converted to civilian use risk being closed. In addition, the Ministry has announced that it will concentrate all of its defense orders in Arzamas-16 and Chelyabinsk-70 and will shut down the weapon production facilities at Avangard and Penza-19 between 2003-2005 (Kudrik 1998; Reuters 1999). With these consolidations approximately 15,000 scientists are expected to lose their jobs.

\section{Atomprom}

As part of his consolidation program, Adamov has resurrected a controversial proposal to divide the Ministry into three separate entities. Under this plan, Minatom would be transformed into a "holding company" composed of the national laboratories, core defense facilities and a new institution called "Atomprom."

According to press statements (Reuters 1998), Atomprom would integrate all of the Ministry's commercial businesses in order to "boost the efficiency and revenues of the nuclear power industry." Profits from Atomprom would then help finance other Minatom projects. Adamov has stated that, despite rumors to the contrary, control of the defense complex will not be handed to the Ministry of Defense and that Atomprom will merely be a structure to bind Minatom's commercial enterprises. All other elements of the nuclear complex will remain under Minatom's control. ${ }^{6}$

The specifics of "Atomprom" and other restructuring proposals remain unknown and it is unclear if the Ministry can divorce its defense facilities from commercial ones.

Difficulties in devising new reporting arrangements, entrenched interest in the current structure and basic bureaucratic resistance to change are expected to stymie attempts to dramatically change the Ministry's organization as well. Nevertheless, there is a growing

\footnotetext{
${ }^{6}$ Former MMBM Minister Vitaly Konovalov originally proposed the creation of Atomprom. He wanted Atomprom to be the unification of all the enterprises involved with the nuclear energy production cyclefrom uranium mining and enrichment to its use in reactors and ultimate disposition. All the military and scientific programs would then be divided between the Ministry of Defense and the Russian Academy of Sciences. Under Konovalov's plan, there would be no Minatom.
} 
realization within the Ministry that the defense complex must be downsized to remain solvent. Reform efforts will therefore continue, even if in fits and starts.

\section{Tightening Central Control Over Subsidiary Agencies}

Like his predecessors, Adamov wants to maintain as much central control over Minatom facilities as he can. Establishing "Atomprom" is central to Adamov's efforts to rein in Minatom's diverse agencies and strengthen his control over their operations. A further example is the consolidation of funds in Konversbank, a financial institution controlled by Minatom. The more subsidiary organizations depend on the central bureaucracy for funding and direction, the less they are able to oppose efforts at being folded into the nascent Atomprom.

Adamov's drive for increased control is seen in his disdain of other government agencies interfering with Minatom affairs. Besides opposing moves for greater regulatory oversight by Gosatomnadzor (GAN), an agency similar to the U.S. Nuclear Regulatory Commission, he has argued that nuclear power plants should be immune from bankruptcy proceedings. Bankruptcy proceedings could place control of reactors with agencies not responsible to Minatom. Losing control in this fashion would complicate Adamov's drives toward consolidation and weaken Minatom's authority over the nation's nuclear complex.

Since taking office, one of Adamov's most contentious fights has been his effort to dominate Rosenergoatom (REA), a semi-autonomous Minatom agency responsible for operating Russia's nuclear power plants. ${ }^{7}$ REA, which enjoys significant independence, stands to lose if Adamov can establish Atomprom and is fighting to maintain its relative independence.

To assert his control, Adamov has replaced men in senior positions at REA. In October 1998 Adamov replaced Yevgeniy Ignatenko, the longstanding head of REA, with Leonid Melomed, a regional energy executive lacking a background in nuclear physics. Given his strong political connections, Ignatenko could not be fired without upsetting too many supporters. He was instead demoted to Deputy Director, an organizational move similar to the one that displaced V. Mikhaylov as Minister of Minatom. Adamov touted Melomed's business and economic skills as necessary to correct REA's financial mismanagement. Melomed's appointment also corresponded with a Minatom-sponsored State General Procurator investigation into REA's financial practices. ${ }^{8}$

While there is undoubtedly some truth to Adamov's claim about fiscal irregularities at REA, such charges could be levied at any government agency, given Russia's crippled economy, rampant use of the barter system and pervasive corruption. Moreover, the results of an audit were reported as being "mostly positive" and insufficient to warrant

\footnotetext{
7 The Leningrad nuclear power plant operates independent of Rosenergoatom.

${ }^{8}$ On January 31, 2000, Melomed was appointed first deputy chairman of the Unified Energy System, non-nuclear energy power utility where he will be responsible for financial issues. Yuri Yakovlev, former head of the Minatom MAKS, has assumed the position of executive director at Rosenergoatom.
} 
the removal of REA executives. As such, Adamov's accusations were more likely an attempt to weaken and put pressure on REA than a desire to promote accurate bookkeeping.

\section{International Programs}

During his tenure as Minister, Viktor Mikhaylov sought to bankroll Minatom programs through the sale of nuclear technologies abroad. This strategy continues under Adamov because the export of nuclear technologies remains one of Minatom's principal sources of revenue and there are few signs that it will be curtailed. Indeed, the financial crisis has encouraged Minatom to find additional clients, often with little regard to their nonproliferation commitments.

Adamov differs from Mikhaylov in his greater attempt to include the Foreign Ministry and other relevant bodies in international projects. This cooperation is not because of a desire for a coordinated Russian foreign policy, but rather a political realization of the consequences of acting too independently. Despite Adamov's preference to oppose any encroachment on domestic Minatom programs by other Ministries, he is relatively open to their support when it comes to international ones. Besides observing what happened to his predecessor, his cooperation is likely based on the realization that as other Ministries get involved, the prospect for a program's eventual success increases. Namely, it becomes more difficult to kill a project as growing numbers become committed to seeing its ultimate success. And with success comes increased funds for Minatom coffers.

Over the past two years, Russia has signed "peaceful nuclear cooperation agreements" or revived deals negotiated prior to the break up of the Soviet Union with Cuba, Iran, Libya and Syria. Minatom has expanded its cooperation with China and India, explored cooperative opportunities with Peru and Indonesia, and has tried to interject itself into the Korean Energy Development Organization (KEDO). While most of these projects are nonstarters or otherwise impractical, given the states involved, all developments should be closely monitored.

\section{Cuba}

After several years on the backburner, Moscow and Havana have resumed voicing their commitments to completing the Juragua (a.k.a. Cienfuegos) nuclear power reactor.

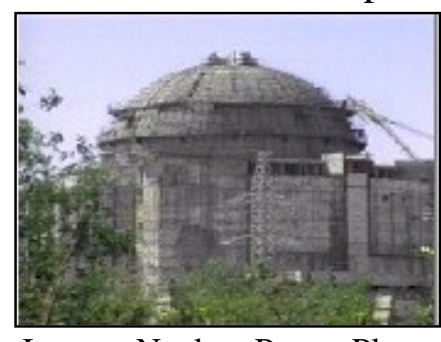

Juragua Nuclear Power Plant
Under a proposal discussed in May 1999, Russia would complete the reactor, take ownership and sell electricity to Cuba. Future profits from the sale of electricity would then be remitted to Russia (Interfax 1999b).

Construction of the VVER-440 reactor began in the early 1980s but was suspended in 1992 because of lacking funds. Observers have estimated that the reactors cement structures are roughly 70 percent complete and its instrumentation and 
safety controls are 20 percent complete (Benjamin-Alvarado 1998). Since then various statements from the countries have indicated that they would like the operation to move forward but generally only if the other party pays for it.

\section{Outlook}

Russian estimates that Juragua can be completed in five to six years are extremely optimistic. Statements from Minatom regarding the resumption of construction are also premature because only the "possibility" of setting up a joint venture to complete the reactor was discussed at the May 1999 meeting of the Intergovernmental Russian-Cuban Commission for Trade, Economic, Scientific and Technical Cooperation (Bazhenova 1999a).

Neither Russia nor Cuba has the money to finish the project. Moreover, given the shaky investment returns and possibility of U.S. sanctions, few countries have shown an interest in contributing to Juragua's completion.

Although Russia's May 1999 proposal indicates that they are now willing to assume financial responsibility, economic realities prohibit meaningful developments on this front. Thus, like many of Russia's recently concluded "peaceful nuclear cooperative agreements" highlighted below, the negotiations with Cuba are more indicative of statements of intent than an actual plan to move forward.

\section{Iran}

In 1995 Tehran and Moscow signed a protocol to complete the partially built Bushehr nuclear reactor, begun by the German firm Siemens but halted after the 1979 Iranian

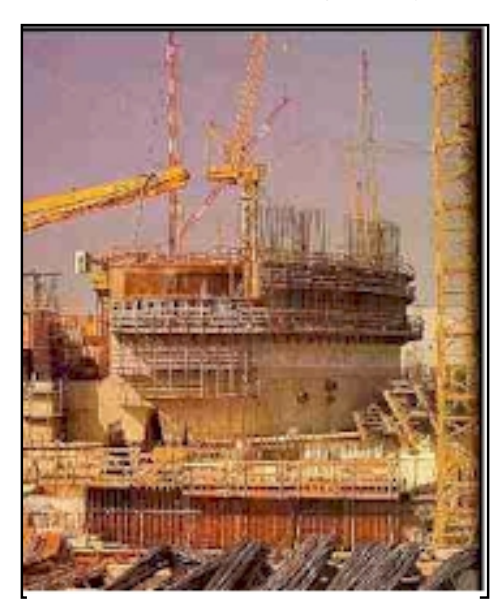

Bushehr Nuclear Power Plant revolution. Minatom resumed work in 1998 (modifying it to a VVER-1000) and expects to finish it around 2004. According to Viktor Mikhaylov, over 600 Russian technicians are working on the project (Mikhaylov 1999). As part of the agreement, Minatom is also training Iranian technicians to operate the plant at the Moscow Institute of Engineering and Physics.

Minatom has used the Bushehr deal as a springboard for other projects in Iran. Technical documentation for a second VVER-1000 at Bushehr has been presented and negotiations for two additional VVER-640 type reactors have begun. Russia and Iran have also discussed developing a uranium mine and building an enrichment facility. 


\section{Outlook}

Minatom is committed to completing Unit 1 of the Bushehr reactor as well as other potential projects. What is unclear, however, is Minatom's motivations for engaging Iran in nuclear projects that could cause a strain in relations with the U.S. No doubt an aspect of Russia is still viewing itself as a "Great Power" and believing it can act accordingly, regardless of the concerns of other nations - the U.S. included. There may also be concerns on the part of the Russian government that it needs to shore-up relations with its southern tier (and Iran) to have some foothold to confront Islamic radicalism. If these concerns were a factor, then Minatom would be an ideal vehicle for attempting to build relations. Whatever the reason, however, Minatom's activities in Iran will continue to be a concern. ${ }^{9}$

\section{Syria}

On May 19, 1999, the Syrian Atomic Energy Commission and Minatom reached an agreement on the cooperation of atomic energy for peaceful purposes. The specifics of the agreement are vague. Various reports from Russian and Syrian news sources indicate that Russia will resume construction of a nuclear research center with either one or two 25-Megawatt light-water reactors. The center is located about 140 kilometers from Damascus (Interfax 1999c; Dubayy Al-Bayan 1999).

Construction of the center, Syria's only nuclear site, was suspended in 1992 because of funding problems. It is estimated that after the disintegration of the Soviet Union, Damascus owed Moscow around \$13 billion (Lyashchenko 1999).

\section{Outlook}

Commenting on the agreement, Minister Adamov stated, "the way of Russia and Syria to the signing of this agreement was a long one. Now it is very important for us to start working on its implementation without delay" (Bazhenova 1999b). Despite Adamov's call for timely implementation, it is doubtful construction could begin within the next five years. There is little reason to believe that the financial roadblocks that initially halted construction have been overcome, and Minatom is already pressed to deliver on existing projects that have been negotiated on a thinly stretched financial base.

\section{China}

Minatom has expanded its nuclear cooperation programs with China under Adamov. In January 1999 Adamov and Liu Zhonbin, Chairman of the Chinese State Commission on National Defense Science, Technology and Industry, reached an agreement to build a nuclear power station near Lianyungang and a gas-centrifugal uranium enrichment plant in Shaanxi province. This will be the first enrichment facility Russia has built abroad. ${ }^{10}$

\footnotetext{
${ }^{9}$ Minatom facilities under U.S. sanctions are the Mendeleyev University of Chemical Technology and the Scientific Research and Design Institute of Power Technology (NIKIET).

${ }^{10}$ Minatom had offered to build an enrichment facility for Iran, but later retracted the proposal.
} 
Other ongoing projects in China include supplying natural uranium, spent fuel reprocessing technology and training Chinese personnel in nuclear safety/reactor operations. Adamov is also lobbying Beijing to purchase an experimental fast-neutron reactor.

\section{Outlook}

China wants to expand its nuclear infrastructure and is building four new nuclear power stations (Xinhua 1999). Minatom clearly sees China as a lucrative market and has bent over backwards to outbid competitors in the United States, Canada and France, even going so far as to build below costs and accept barter as a partial means of payment. While Minatom realizes that it will not make much money on the Lianyungang project, it sees the project as a gateway to a potentially vast and profitable Chinese market.

\section{India}

Under a 1988 agreement, the Soviet Union agreed to provide India with two VVER1000s at Koodankulam in Tamil Nadu province. Construction was supposed to begin in 1992, but financial constraints in Russia and India delayed the project until a new contract was reached in 1998. The price for the first unit is reported to be $\$ 2$ billion (Interfax Weekly Business Report 1999). India's decision to resume nuclear testing in May 1998 had no effect on Russia's negotiations to supply India with nuclear reactors.

\section{Outlook}

Despite the 1998 agreement, construction of the reactor is still years away. Work began in June 1999 on the "Detailed Project Report" for the reactors, but completion of this document is not expected before 2001. According to the Indian newspaper, The Hindu (1999), "On the completion of the report, the Indian atomic energy establishment would start the process of approval." There are undoubtedly several layers of bureaucracy that must grant approval for this document. The length of this process is questionable.

\section{Libya}

In October 1997 the Russian Foreign Ministry announced that Russian companies were prepared to "help in technical servicing and reconstruction of the maintenance system of the Tajurah Nuclear Research Center which was built with Russian assistance"

(Reuters 1997). Five months later, the Minatom firm Atomenergoeksport signed an $\$ 8$ million contract for the partial overhaul of the research center near Tripoli. Economic hardship in Russia and United Nations' imposed sanctions against Libya, however, rendered the statement little more than a policy goal of future cooperation.

Prospects for Russian/Libyan nuclear cooperation improved with Libya's April 1999 decision to surrender two suspects indicted for the 1988 Pan Am airliner bombing over Lockerbie, Scotland. Russia, which is owed \$3 billion from Libya on Soviet-era debts, hopes to capitalize on this development and has sought an end to the U.N. sanctions. In 
addition to the Tajurah project, Soviet-era proposals to build reactors in Sirt and Sultan will likely receive renewed attention.

\section{Outlook}

The Tajurah research center comprises a Soviet designed 10-megawatt reactor managed by a staff of 750. Despite the prospect of ending sanctions, movement on the reactor projects will not likely begin anytime soon. According to the London Foreign Report (1999), “[Libya's] nuclear programme has lacked well-developed plans, technical expertise, consistent financing and sufficient support from foreign suppliers." The more grandiose proposals are also merely ideas, not firm commitments. Nevertheless, given Libya's pursuit of weapons of mass destruction, any developments in their nuclear infrastructure warrant scrutiny.

\section{Peru}

On May 14, 1999, the Executive Director of the Peruvian Nuclear Energy Institute, Conrado Seminario, met with Minister Adamov and reportedly expressed an interest in cooperating in the peaceful uses of nuclear energy. The Russian news agency Tass quotes him as stating that Peru is "considering the possibility of using nuclear energy 'on the medium term", (Interfax 1999a).

At the meeting, Seminario also stated his intent to purchase a Russian installation for disinfecting food and produce by means of radiation. Peru has used such Russian equipment since 1996 and is seeking equipment capable of a greater capacity to handle fishmeal. Minatom reports that the new installation will cost $\$ 25$ to $\$ 30$ million (Interfax 1999a).

\section{Outlook}

Peru does not currently possess any nuclear reactors and Seminario's statement reveals only a passing interest in development of nuclear energy. It is doubtful there will be any serious movement on this front in the near future. His intent to purchase a Russian installation for disinfecting food is more likely but is innocuous and is not a cause for concern. With respect to nuclear safety and security, Minatom involvement in Peru over the next decade will be inconsequential.

\section{South Korea}

Minatom's involvement with South Korea is mostly limited to providing reactor fuel; but Minatom is striving to increase its presence on the Peninsula. The Ministry has sought to interject itself into the Korean Energy Development Organization (KEDO) and is proposing to build reactors in the Far East for electricity export to North Korea. Thus far, the United States and Japan have rebuffed its efforts. 
Despite being denied membership in KEDO, however, Russia has moved to formalize nuclear cooperation with South Korea. In May 1999 Minister Adamov and Korean Foreign Affairs and Trade Minister Hong Soon-Young signed an agreement calling for cooperation in the design and construction of nuclear reactors. According to Itar-Tass, the document envisages cooperation in nuclear power engineering, the nuclear fuel cycle, use of radioactive isotopes in agriculture, medicine and industry and in nuclear safety (Bazhenova 1999c). The agreement will remain in force for ten years and prohibits the use of any nuclear materials and equipment transferred between the states in the manufacture of nuclear weapons (Yonhap 1999b).

\section{Outlook}

The May 1999 agreement essentially upgrades a 1994 protocol on cooperation in the peaceful use of nuclear energy to the government level. Based on press reports, it does not propose any concrete programs but simply serves as a symbolic step toward the possibility of greater cooperation.

The two states have also reportedly agreed to resume meetings on the development of laser and nuclear fusion technology (Yonhap 1999a). It is unclear if the prohibition on transferring nuclear materials and equipment in the manufacturing of nuclear weapons that is stipulated in the May 1999 agreement applies to research in this area as well. Although there are no direct or immediate proliferation concerns associated with fusion research, efforts to promote greater transparency in this field are encouraged.

\section{Other International Projects}

Minatom has explored other cooperative projects that have not yet developed to the extent as the projects mentioned above. Among these projects are negotiations with Indonesia to supply the island nation with several floating reactors and discussions with Canada on the construction of a CANDU reactor near the Russian/Chinese border. Under that plan, Russia would raise income through the sale of electricity from the CANDU reactor to China—similar to their proposed idea for North Korea.

However, programs for the export of Russian electricity are unlikely. Funds are simply not available for construction of new reactors. Moreover, when resources do become available, they will likely be obligated to existing, partially completed projects serving domestic needs.

\section{Waste Management}

Under Adamov's leadership, treatment of spent fuel and radioactive waste has become an important issue on the Ministry's agenda while also assuming an international dimension. A pressing need exists for new storage space and to repair or decommission existing space. Specifically, Minatom wants to build new centers and modernize existing 
structures to handle spent fuel. Projects include seeking control over the "Radon" enterprises (regional waste centers), which are administered by the Ministry of Construction, building a permanent radioactive waste disposal facility at Novaya Zemlaya, and completing the RT-2 spent fuel-reprocessing plant at Krasnoyarsk-26. Minatom has also broadened its waste management mandate by taking over the responsibility of decommissioning nuclear submarines from the Ministry of Defense.

Minatom views waste management as a largely untapped source of financial gain, which (as explained below) accounts for its acquisition of the submarine mission and its attempts to acquire control over the Radons. Many facilities are also being opened to outside sources as a means of highlighting the environmental concerns posed by the dilapidated buildings. Minatom appears to be using the potential for an environmental calamity from poor handling of nuclear waste as leverage to secure extra State budgetary dollars and greater amounts of international assistance.

\section{Importing Spent Fuel for Reprocessing and Permanent Disposition}

Minatom's greatest obstacle to building new domestic facilities and implementing a variety of programs and plans is a lack of funds. To raise the necessary hard currency to initiate or complete various projects, Adamov wants to import spent fuel from foreign states for reprocessing and permanent disposal. Payments for these services would be then invested into new or existing construction projects and other assorted programs. The Russian Government and State Duma are currently reviewing this plan.

Efforts to raise funds through the import and storage of foreign spent fuel have been around for a several years. In 1995 the Ministry and governing officials in Krasnoyarsk Kray quietly submitted a proposal to President Yeltsin to allow Krasnoyarsk-26's RT-2 reprocessing plant to accept spent fuel from foreign reactors for reprocessing and storage. Their proposal was accepted as part of a presidential edict signed on January 25, 1995, "On State Support for the Restructuring and Conversion of the Atomic Industry in the City of Zhelezenogorsk, Krasnoyarsk Kray." About a month later, however, the State Duma realized that the edict was contrary to federal law, and the provision to allow the import of spent fuel was retracted. Since then, Minatom had sought to amend the legislation, but this amendment was relatively low on their list of priorities.

Under Adamov, the importation of spent nuclear fuel has received renewed attention. News of Adamov's plans broke in January 1999 when the environmental group Greenpeace released documents exposing negotiations between Minatom and representatives of German and Swiss firms. According to a protocol negotiated by the two sides, Russia would accept 10,000 tons of spent fuel over thirty years for reprocessing and/or long-term storage for $\$ 10$ billion. Uranium and plutonium recovered from the fuel could be returned to the exporting state while the radioactive by-products would remain in Russia. Other states reportedly interested in sending their waste to Russia include Spain, South Korea, Taiwan and possibly Japan (Greenpeace 1999). 
The Ministry wanted the negotiations to remain secret because importing spent fuel for permanent disposition is illegal under Russia's environmental protection laws, but readily confirmed the documents' authenticity after they were publicized. Existing legislation prohibits any import of radioactive materials. Consequently, Minatom has initiated an intensive lobbying campaign to amend the federal legislation to define spent fuel apart from radioactive wastes. If accepted, foreign spent fuel would be reclassified as an energy resource eligible for import (Kudrik 1999a).

To achieve parliamentary approval, the Ministry has touted the financial benefits of accepting foreign spent fuel and has even offered to lend the government $\$ 5$ billion earned from the proceeds over 20 years. In proposing this lending arrangement, Adamov has sought to capitalize on Western resentment by contrasting a loan from Minatom as being more agreeable than one from the International Monetary Fund (Piskunov 1999).

Even without Minatom's offer, proposals to amend Russia's environmental laws enjoy strong support within the Duma. Movement, however, has been slow. In June 1999 the Russian news service Interfax Daily (1999a) quoted Minister Adamov as saying that he hoped the changes would pass by December 1999. Adamov, however, faced a setback in August 1999 when the Russian Cabinet failed to decide on whether it would support the

amendment. Then Prime Minister Vladimir Putin reportedly stated that the issue should be agreed to by every member of government before being put to a vote (Interfax Daily 1999b). Despite this delay, considering the country's financial shortcomings and history of lax environmental laws, the amended legislation will likely be approved.

If approved, foreign spent fuel shipments will be reprocessed at Mayak's RT-1 plant. The proceeds would then be divided between finishing the Krasnoyarsk's RT-2 reprocessing plant and selecting a permanent burial site for the radioactive byproducts. Minatom estimates that with the completion of the RT-2 plant, they will be able to reprocess 1,500 tonnes of spent fuel each year (Kudrik 1999b).

\section{Non-Proliferation Trust, Inc.}

Parallel to Ministry's efforts to import foreign spent fuel, Adamov is working with NonProliferation Trust, Inc. (NPT), a private U.S.-based consulting firm, to host an international spent fuel storage facility in Russia. Movement on this structure would depend on amending legislation on environment protection and securing the support of both Washington and Moscow. Washington's support is needed because much of the fuel that would be handled by NPT is of U.S. origin.

Under this arrangement, NPT would finance the construction of a storage facility housing 10,000 metric tons of foreign spent fuel from commercial power sources for 40 years, none of which could be reprocessed. What will become of the spent fuel after the contractual 40-year time period is open to speculation. Possible outcomes include remaining in storage, burial in a Russian repository, or transfer to another storage site such as the Pacific Atoll of Wake Island (Perera 1999). Minatom itself might also take 
title to the material and decide to reprocess the spent fuel, although NPT is working on safeguards to preclude this potentiality.

Proceeds from storing the spent fuel, based on NPT's revenue projections, would be dispersed as follows:

- $\$ 3$ billion for cleanup of contaminated sites and other environmental initiatives;

- $\$ 1.8$ billion (at least) to site, qualify and construct a geologic repository for spent fuel and high-level nuclear waste;

- $\$ 1.5$ billion to improve physical security and material control and accounting of weapon-usable fissile materials;

- \$2 billion for a general fund to create and foster conversion programs in Russia's "nuclear cities" and additional programs for radiological cleanup, nuclear material cleanup and repository development;

- $\$ 2$ billion for economic support for senior citizens; and

- \$250 million to support orphans and orphanages (Cochran and Greene 1999).

The prospects for the NPT facility are greater than many of the other projects Minatom is aligned with, provided Adamov agrees not to reprocess the stored spent fuel after the 40year time line. On this point, he has waffled. If he does formally agree not to reprocess — which is by no means certain — a principal U.S. objection to the project will have been removed (Knapik and Sains 1999).

\section{Permanent Disposal Facility}

Much of Russia's waste management problems stem from insufficient storage space and lack of a permanent disposal facility. Given the importance Minatom is attaching to waste management, efforts have increased to find a suitable site for final disposition. Deep burial in Novaya Zemla's permafrost north of Arkhangelsk is a leading contender, and has been studied on and off since 1991. Other sites being considered include deep burial in granite formations on the Kola Peninsula, at Krasnoyarsk-26, or in porphyrite at Chelyabinsk-65 (Perera 1999).

The plan for disposition at Novaya Zemla, the site with the greatest promise, calls for placing radioactive waste in the permafrost at a depth lower than the layer of seasonal thawing. Proposed construction of 14-meter deep holds and trenches would allow for the burial of 3,000 cubic meters of waste (Rybak 1997). The facility would be primarily used for low and medium level radioactive waste from the Northern Naval Fleet, icebreaker fleet and enterprises in Murmansk and Arkhangelks Oblasts (Kondratkova 1999). Given Russia's need for a facility to hold all types of waste, however, it is possible the site will be designed to accommodate a variety of radioactive 
materials. Moreover, in 1995 Mikhaylov cited Novaya Zemlya as a potential site for a regional nuclear waste storage facility. Adamov may reinitiate Mikhaylov's proposal as part of the effort to raise funds through the acceptance of foreign nuclear waste.

As with most Minatom's projects, progress has been delayed due to financial constraints. Prospects for the storage facility, however, have improved in light of an April 1999 contribution of 16 million Kroner (approximately $\$ 2$ million) from Norway to conduct a safety assessment of the proposed facility - a clear indication that Oslo believes burial in permafrost is a viable option (Ove Arsaether 1999). Moreover, the Non-Proliferation Trust, Inc. has offered $\$ 1.8$ billion towards the selection and construction of a permanent disposal facility if their plan to store foreign spent fuel in Russia is accepted. Given that the cost of the site is projected to be $\$ 140$ million, there appears to be ample funding to ensure its realization.

The storage facility also reportedly enjoys a high degree of government and interagency support. It has been approved by the State Committee on the North's Commission on Arctic and Antarctic Affairs and accepted by the Ministry of Health, Gosatomnadzor and the Ministry of Geology and Natural Resources (Kondratkova 1999). Moreover, given the sparsely populated region, public protest, which has hindered completion of other Minatom projects, such as the RT-2 plant at Krasnoyarsk-26, is not likely to present a significant obstacle.

\section{Submarine Decommissioning and Control of Radons}

Minatom has sought to expand its influence over all forms of radioactive waste management. Shortly after becoming Minister, Adamov reiterated Minatom's desire to take control over the Radon regional waste storage facilities, which are controlled by the Ministry of Construction, and designed to handle radioactive byproducts generated outside the fuel cycle, e.g. medical, research and industrial wastes. Later, in May 1998 it was announced that the Ministry was assuming full responsibility for the decommissioning of nuclear submarines. ${ }^{11}$

The goal to take control of the Radons was reiterated at a February 1999 meeting of Minatom's Board of Directors. It is unclear, however, if Adamov supports Mikahylov's idea of using the Radons as potential sites for regional nuclear waste storage or if he wants to maintain them purely as reservoirs for byproducts generated outside the fuel cycle. Even if the later is true, they still could potentially be used to store wastes from foreign countries. At the moment, Minatom's goal is simply to fold them into Minatom's expansive nuclear apparatus.

Minatom's decision to seek control of the Radons and acceptance of the submarine decommissioning responsibility, appears to stem from a belief that waste management is simply another product line for Minatom to control. These additional markets, Minatom

\footnotetext{
${ }^{11}$ The Navy was fully willing to divest itself of the decommissioning mandate. It is unclear how the Ministry of Construction feels about relinquishing control of the Radon enterprises.
} 
hopes, will translate into new avenues for capturing sources of revenue that had previously gone to other federal bodies.

Its strategy for raising funds with the Radons will likely mimic the one emerging around their new submarine decommissioning responsibility. Namely, to assert control over the facilities and then declare that the Ministry is financially incapable of managing the large volumes of waste. Then, by publicizing potential environmental concerns of the dilapidated facilities and raising fears of radioactive contamination, they are positioned to potentially receive greater amounts of state assistance. This is a risky strategy, however, considering that the Ministry of Defense largely agreed to give up the submarine mission because they could not get any State support. Why Minatom feels it will be more successful is unclear. Should they fail, the submarine dismantling mission will be an enormous drain on an already low budget.

Despite cloudy prospects for garnering State funds, their strategy is paying off on the international level. Given that environmental concerns cross state boundaries, Minatom is positioned to receive foreign assistance that would have otherwise gone to other Russian agencies. Nunn-Lugar Cooperative Threat Reduction dollars for submarine decommissioning that had gone to the Ministry of Defense, for example, are now directed to Minatom, as is financial assistance from Japan and other international donors.

By assuming control of submarine decommissioning, the veil of secrecy surrounding the naval fuel cycle has significantly lifted. As the extent of the environmental threat becomes more widely known, Minatom will undoubtedly stress the need for greater assistance in environmental cleanup. Although a percentage of funds donated for this cause will surely go to worthy projects, it is also likely that a large portion will be diverted to programs deemed of greater importance to Minatom's senior leadership. For despite various press-statements to the contrary, righting the environmental wrongs of the Soviet nuclear past is fairly low on Minatom's list of priorities. 


\section{References}

Bazhenova A. May 12, 1999a. "Russia Views Completion of Cuban Nuclear Power Plant.”Itar-Tass. Available in FBIS Document ID: FTS19990512000579.

Bazhenova A. May 19, 1999b. "Russia, Syria Sign Agreement on Peaceful Atomic Energy.” Itar-Tass. Available in FBIS Document ID: FTS19990519000969.

Bashenova A. May 28, 1999c. "Russia and South Korea Today Signed an Agreement on Broad Use of Nuclear Energy for Peaceful Purposes." Itar-Tass. Available in FBIS Document ID: FTS19990528000553.

Benjamin-Alvarado B. February 15, 1998. Interview with Jonathan Benjamin-Alvarado of University of Georgia's Center for International Trade and Security on "A 'Chernobyl' in Cuba.” America's Defense Monitor Program No. 1123. Washington, DC: Center for Defense Information.

Cochran T and W. Greene. No date. "NPT Disagrees with Bellona." Letter from Thomas Cochran and Wade Greene to Bellona Foundation. Reproduced on URL: http://www.bellona.no/e/russia/cochran_answer.htm.

Dubayy Al-Bayan. May 23, 1999. "Syria Gets Nuclear Reactors from Russia." Available in FBIS Document ID: FTS19990530000096.

Greenpeace. January 23, 1999. "New Leaked Document Reveals Plans to Dump European and Asian Nuclear Waste in Russia." Available URL: www.greenpeace.org/pressrelease/nucwaste/1999jan23.html.

The Hindu. June 24, 1999. "India, Russia Begins Work on Nuclear Power Project." Available in FBIS Document ID: FTS19990624000927.

Interfax. May 14, 1999a. "Peru Interested in Nuclear Cooperation with Russia." Available in FBIS Document ID: FTS19990514001391.

Interfax. May 18, 1999b. "Russia: Cuban Nuclear Plant to Cost \$500-\$600 Million." Available in FBIS Document ID: FTS19990518000867.

Interfax. May 20, 1999c. "Russia to Construct Syrian Nuclear Research Center." Available in FBIS Document ID: FTS19990520001548.

Interfax Daily Business Report. June 21, 1999a. "Atomic Ministry May Earn Over \$10 Billion - Adamov." VIII(135):2058. Available in FBIS Document ID:

FTS19990720001468. 
Interfax Daily Business Report. August 26, 1999b. "Import of Radioactive Materials for Russian Storage Not Yet Decided." Available in FBIS Document ID:

FTS19990826001275.

Interfax Weekly Business Report. May 11, 1999. "Russia, India Discuss Nuclear Power Plant Project.” Available in FBIS Document ID: FTS19990511001989.

Itar-Tass. October 25, 1999. "Russia: Putin Strips Deputy Energy Minister of Duties." Available in FBIS Document ID: FTS19991025001273.

Khripunov I. May/June 1999. "Minatom at the Edge." Bulletin of the Atomic Scientists 55(3):56.

Knapik M. and A. Sains. August 23, 1999. "Proposal to Store Foreign Spent Fuel In Russia Criticized, Defended." Nuclear Fuel 24(17):17.

Kondratkova M. April 1999. "Novaya Zemlya: Unexpected View on Possibility of Use," Elektrostal Atompressa 13:344. Available in FBIS Document ID: FTS19990602001203.

Kudrik I. July 7, 1998. "Russian Government Restructures Defense Industry: Minatom Plans to Cut Military Enterprises." Bellona. Available URL:

http://www.bellona.no/e/russia/980715-2.html.

Kudrik I. August 23 1999a. "Minatom Sticks to Reprocessing," Bellona. Available URL: http://www.bellona.no/e/russia/990823.htm.

Kudrik I. August 26, 1999b. "Minatom Loses First Round.” Bellona. Available URL: http://www.bellona.no/russia/990826.htm.

London Foreign Report. April 20, 1999. "Post-Sanction Deals Between Libya, Russia Described.” Available in FBIS Document ID: FTS19990421001701.

Lyashchenko A. July 9, 1999. “Damascus is Still Moscow's Partner: Results of Syrian President's Visit to Our Country." Krasnaya Zvezda. Available in FBIS Document ID: FTS19990713001527.

Mikhaylov V. March-April 1999. "Polemics: Minatom and International Cooperation." Yadernyy Kontrol Digest 44:2. Available in FBIS Document ID: FTS19990621001180.

Ove Arsaether J. April 18, 1999. "Norwegian Experts to Assess Safety..." Aftenposten. Available in FBIS Document ID: FTS1990423000517.

Perera, J. June 10, 1999. "Industry Group Proposes Russia Market SF Storage Internationally." Nuclear Waste News 19(23). 
Piskunov G. June 23, 1999. "Minatom to Offer Government Long Term Loan.” Rossiyskaya Gazet. Available in FBIS Document ID: FTS19990625001783.

Reuters. October 23, 1997. "Russia to Help Libya Reconstruct Nuclear Reactor."

Reuters. November 17, 1998. "Russian Ministry Proposes Nuclear Holding Firm."

Reuters. February 10, 1999. "Russia to Switch Nuclear Emphasis from Military to Civilian."

Rybak S. October 23, 1997. "Russian LLW Disposal Facility is Planned for Nobaya Zemlya." Nucleonics Week 38(43):14.

Xinhua. May 24, 1999. "Priority to Coastal Areas in Developing Nuclear Power." Available in FBIS Document ID: FTS19990525001633.

Yadernyy Kontrol Digest. (Spring 1999) "Minatom Reviews 1998, Making Plans for 1999.” No. 10. Available in PIR Center URL: http://www.pircenter.org/yke/index.htm.

Yonhap. April 8, 1999a. "ROK, Russia Initial Pact on Nuclear Energy." Available in FBIS Document ID: FTS19990408000235.

Yonhap. May 28, 1999b. "ROK, Russia Sign Legal, Nuclear Energy Treaties." Available in FBIS Document ID: FTS19990528000166. 


\section{APPENDIX A}

Organization of the Ministry of Atomic Energy 


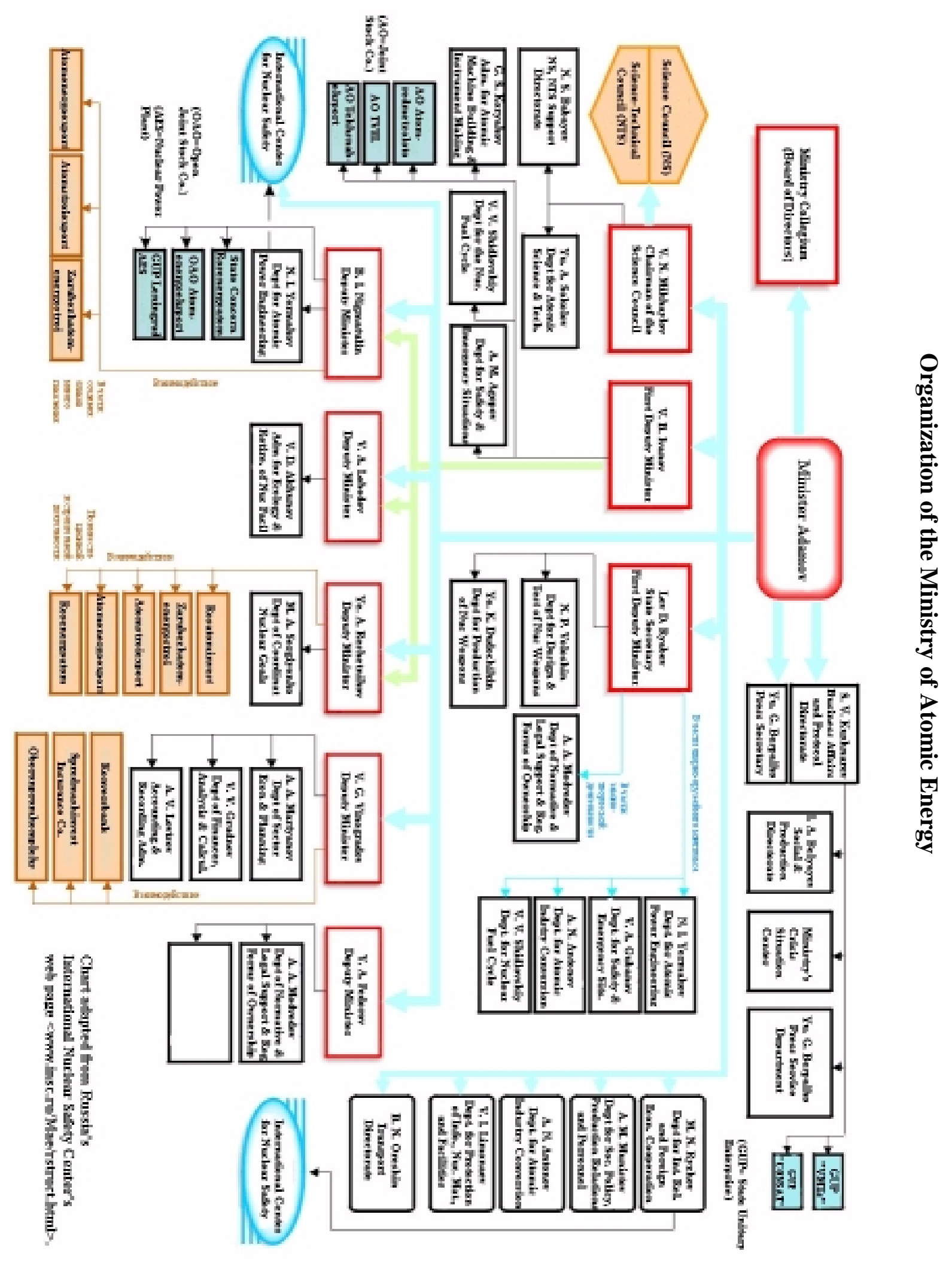




\section{APPENDIX B}

Directors of Minatom and Predecessor Institutions 


\begin{tabular}{|c|c|}
\hline \multicolumn{2}{|c|}{ Directors of Minatom and Predecessor Institutions } \\
\hline Yevgeny Adamov, Minister, Minatom & March 4, 1998 - present \\
\hline Victor Mikhaylov, Minister, Minatom & March 2, 1992 - March 2, 1998 \\
\hline $\begin{array}{c}\text { Boris V. Nikipelov and Viktor Sidorenko, } \\
\text { Acting Ministers, MAPI/Minatom }\end{array}$ & September 1991 - March 1992 \\
\hline Vitaly F. Konovalov, Minister, MAPI & 1989 - August 1991 \\
\hline Lev D. Ryabev, Minister, MMMB & 1986 - 1989 \\
\hline Yefim P. Slavsky, Minister, MMMB & August 1945 - 1953 - 1963 \\
\hline $\begin{array}{c}\text { MMMB: Ministry of Medium Machine Building } \\
\text { PGU: First Main Directorate of the Soviet Council of Ministers }\end{array}$ \\
\hline Mikhail G. Pervukhin, Minister, MMMB \\
Byacheslav A. Malyshev, Minister, MMMB \\
Boris L. Vannikov, Acting Minister, MMMB \\
\hline Avraami P. Zaveniagin, Minister, MMMB \\
\hline
\end{tabular}


APPENDIX C

The Russian Federation Ministry of Atomic Energy (MINATOM) 


\section{The Russian Federation Ministry of Atomic Energy (MINATOM)}

Department of Energy
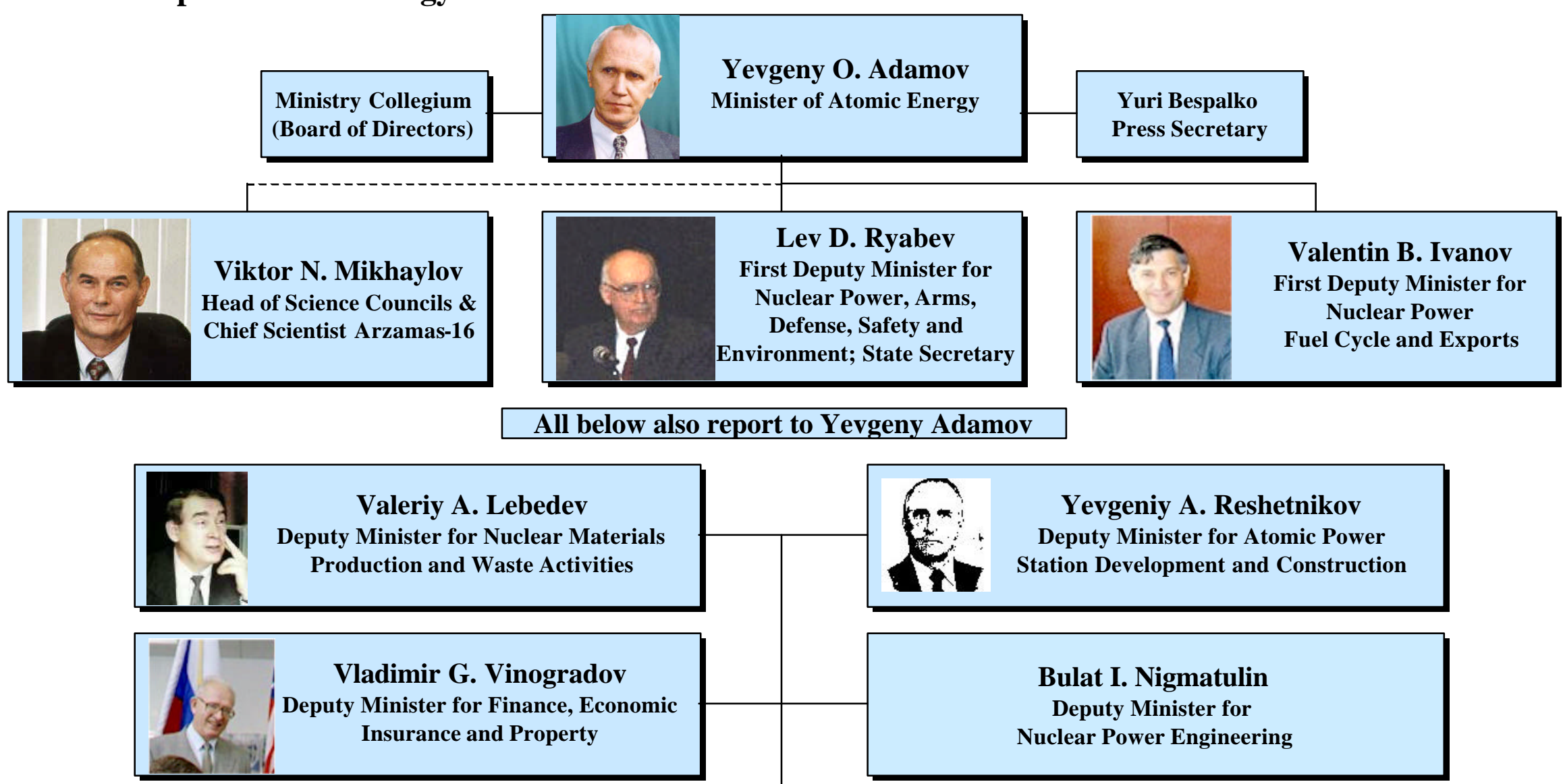

Yevgeniy A. Reshetnikov

Deputy Minister for Atomic Power

Station Development and Construction

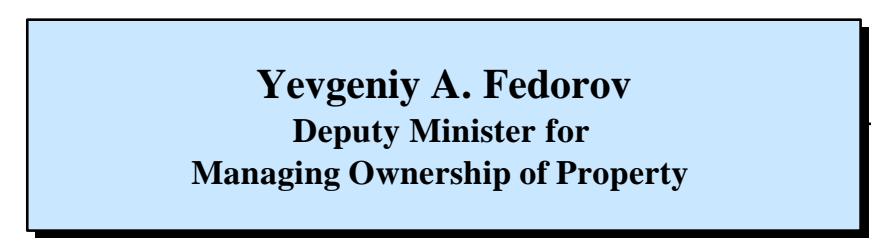

Bulat I. Nigmatulin

Deputy Minister for

Nuclear Power Engineering 


\section{Other Key Minatom Officials Reporting to Minister Adamov}

Department of Energy

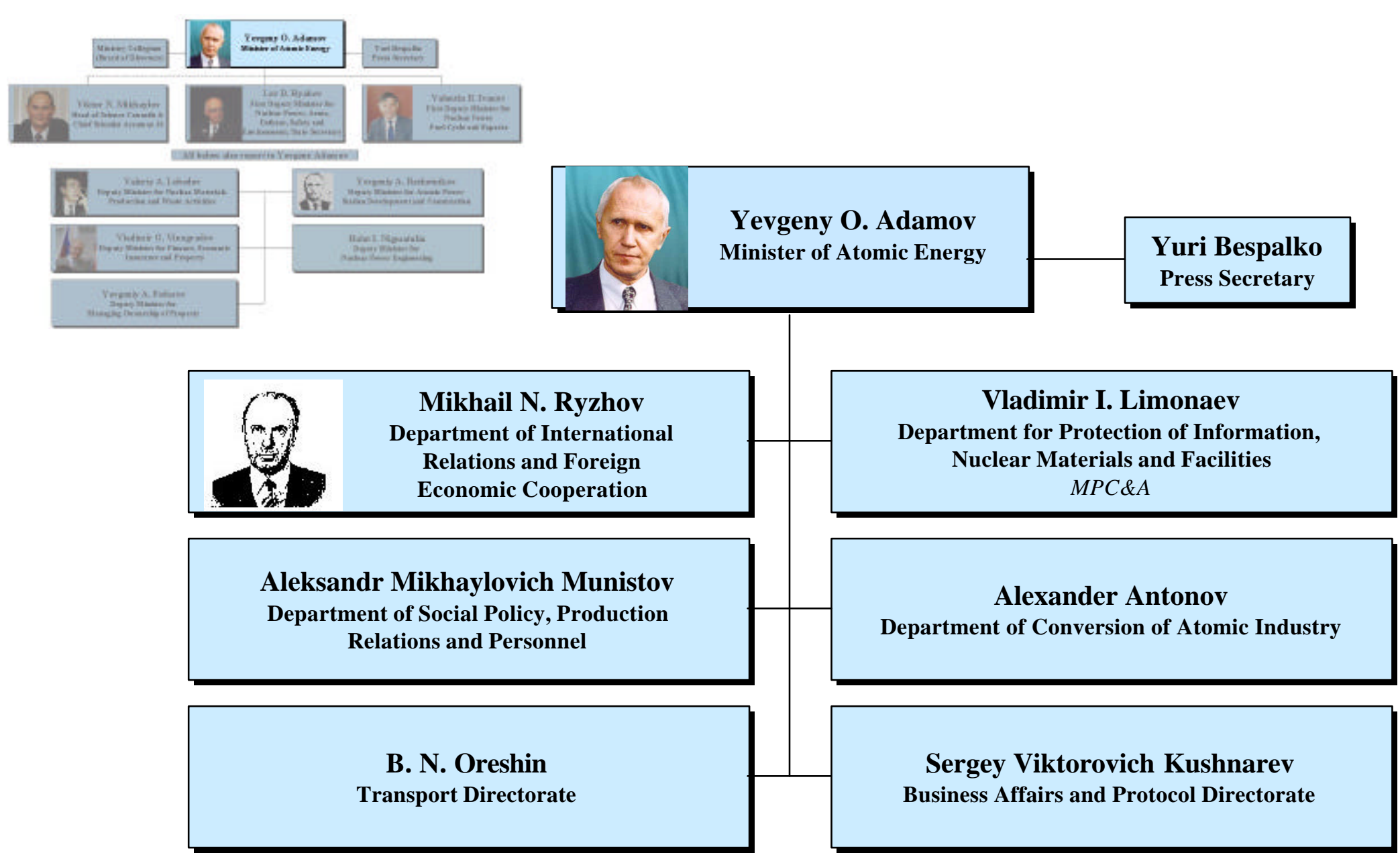




\section{Key Organizations Reporting to the First Deputy Minister for Nuclear Power, Arms, Defense, Safety and Environment}

Department of Energy

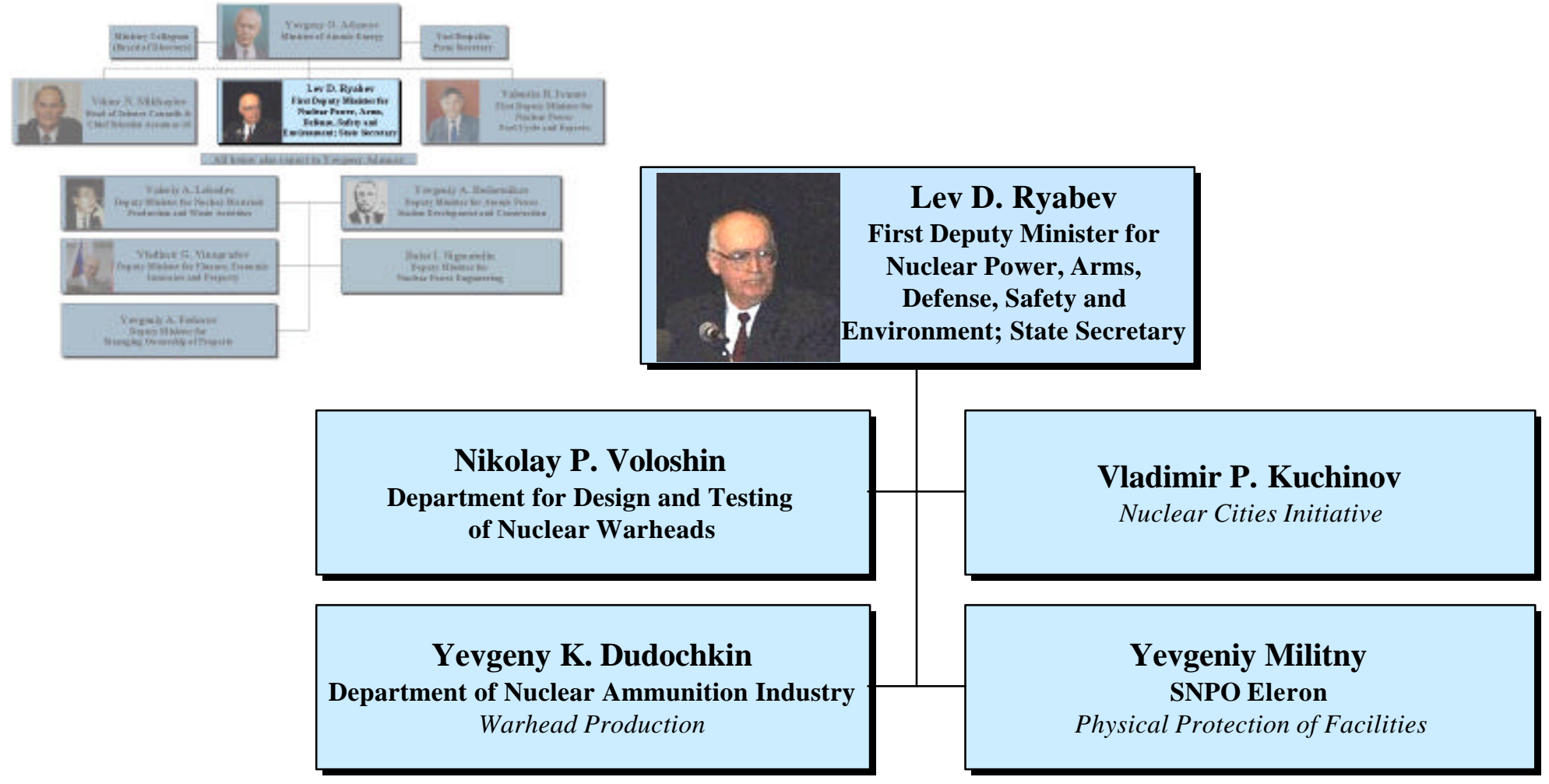




\section{Organizations Reporting to the First Deputy Minister for Nuclear Power, Arms, Defense, Safety and Environment (for issues concerning the nuclear weapons complex)}

Department of Energy
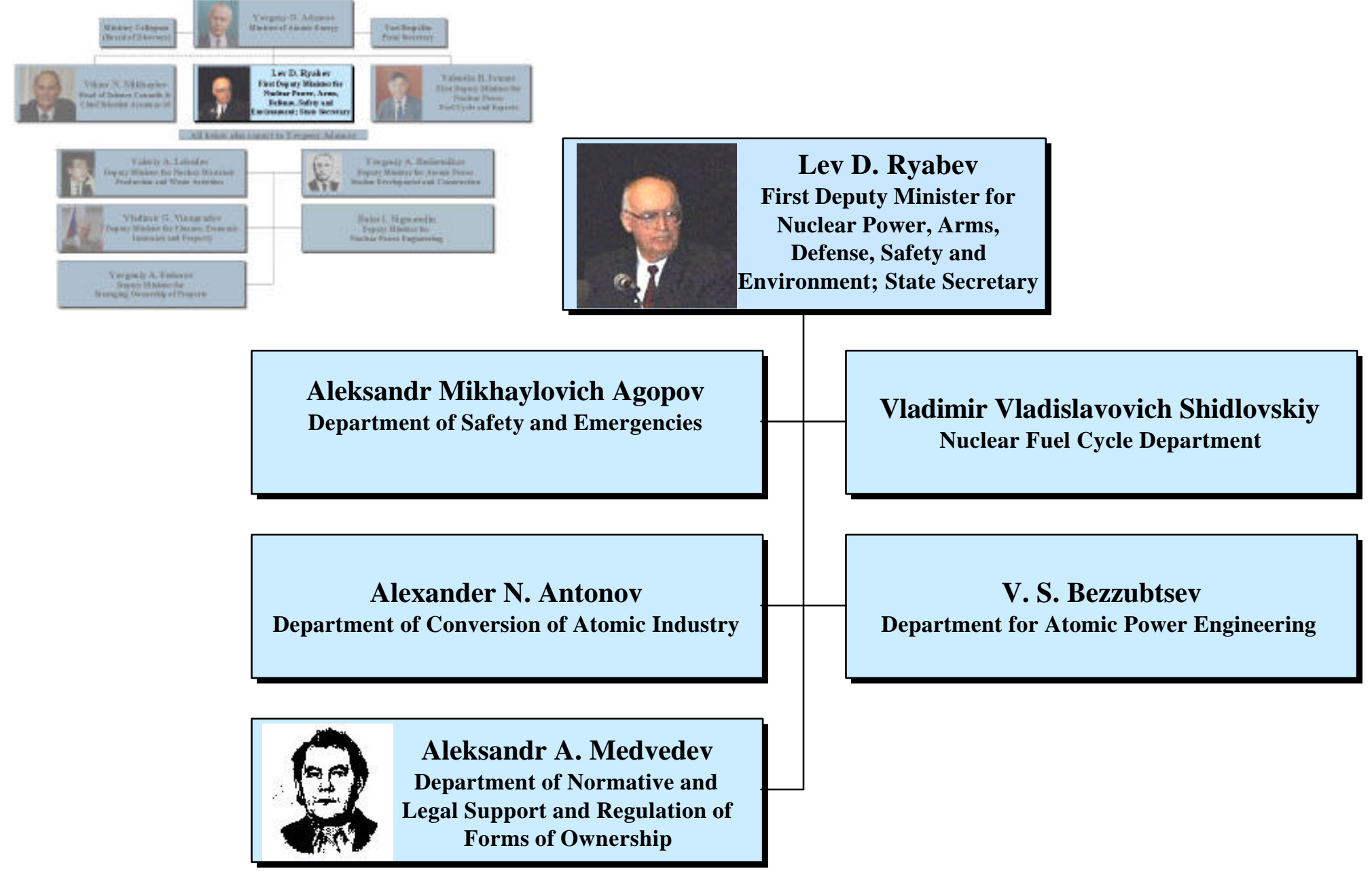


\section{Key Organizations Reporting to the First Deputy Minister for Nuclear Power, Fuel Cycle, \& Exports}

Department of Energy
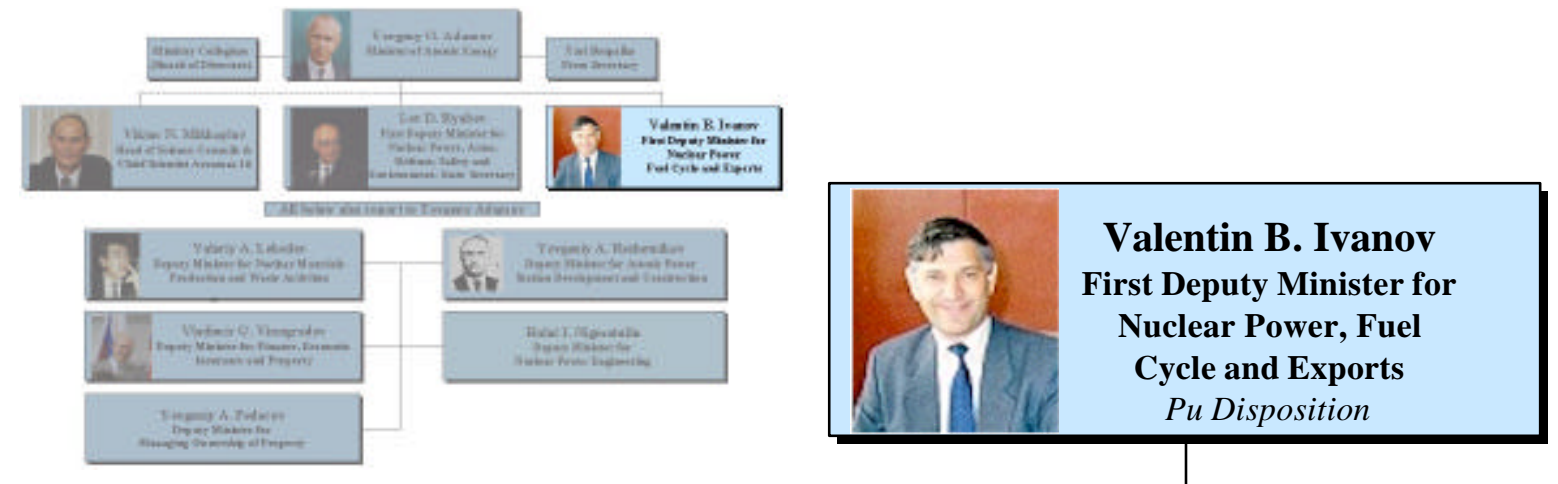

Aleksandr Mikhaylovich Agopov Department of Safety and Emergency Situations
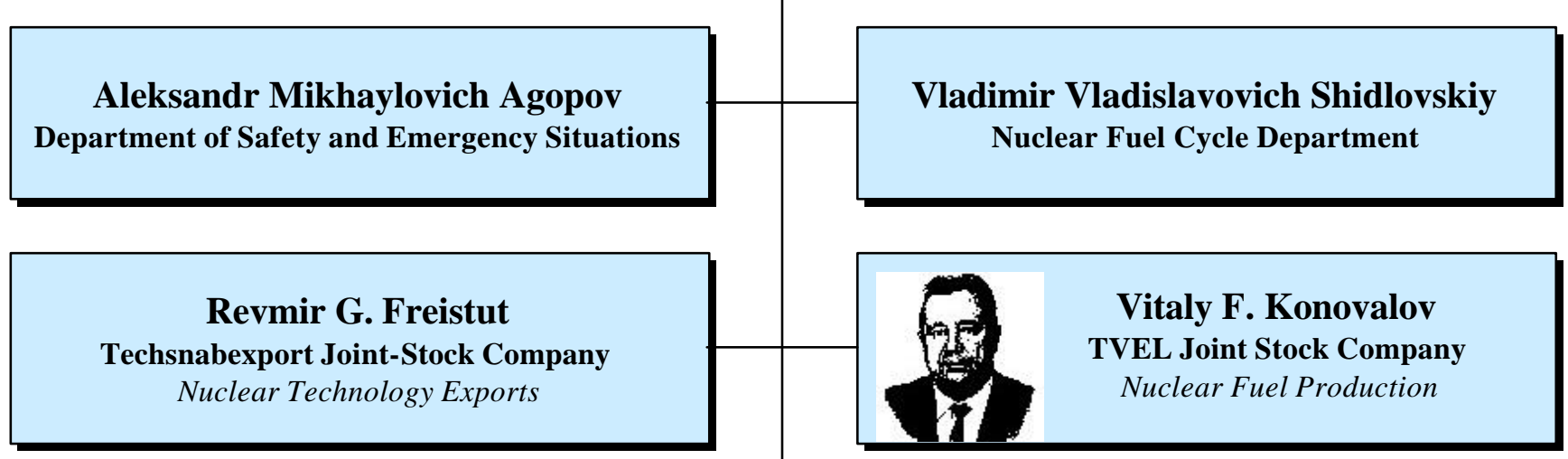

Gennady S. Koryakov

Administration for Atomic Machine Building and Instrument Making

\section{Vyasheslav Korotkov \\ Atomredmetzoloto Joint-Stock Company \\ Uranium Mining Industries}




\section{Key Organizations Reporting to the Chief of the Science Councils}

Department of Energy
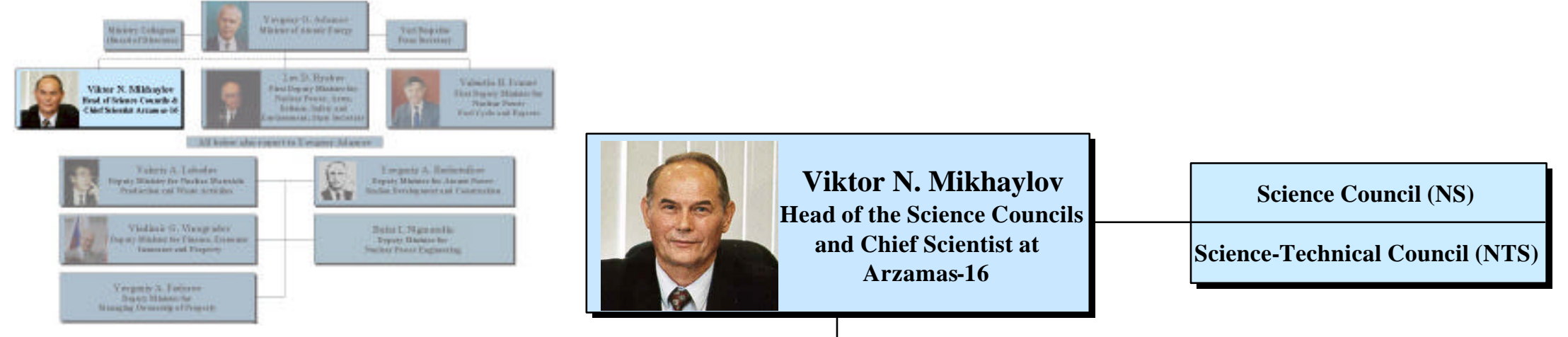

Department of Atomic Science and Engineering

Nikolai S. Babaev

NS, NTS

Support Directorate

On October 25, 1999 Viktor Mikhaylov was "relieved of his duties as

First Deputy Minister." He remains the head of the two

Science Councils and the Chief Scientist at Arzamas-16. 


\section{Key Organizations Reporting to the Deputy Minister for Nuclear Material Production \& Waste}

Department of Energy
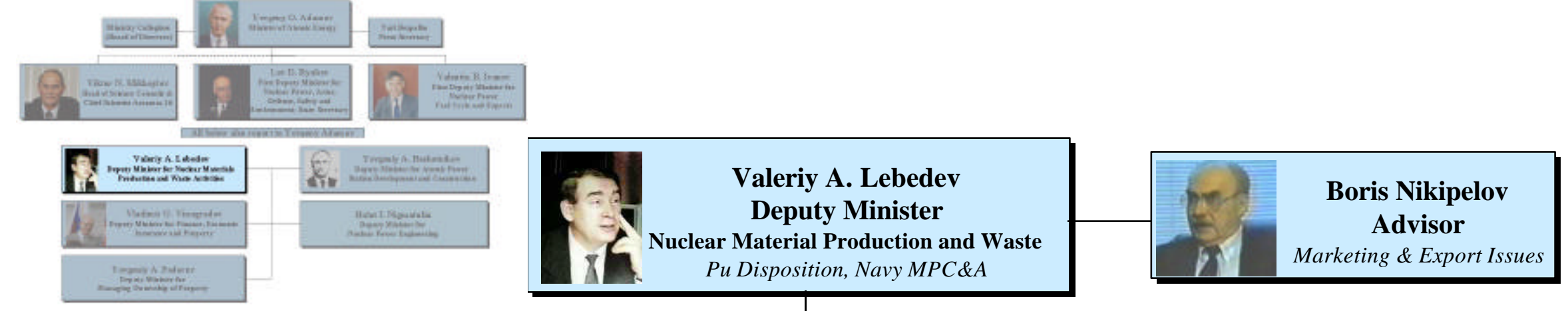

Victor D. Akhunov

Administration for Ecology and

Retirement of Nuclear Facilities

Submarine decommissioning 


\section{Key Organizations Reporting to the Deputy Minister for Atomic Power Station Development and Construction}

Department of Energy

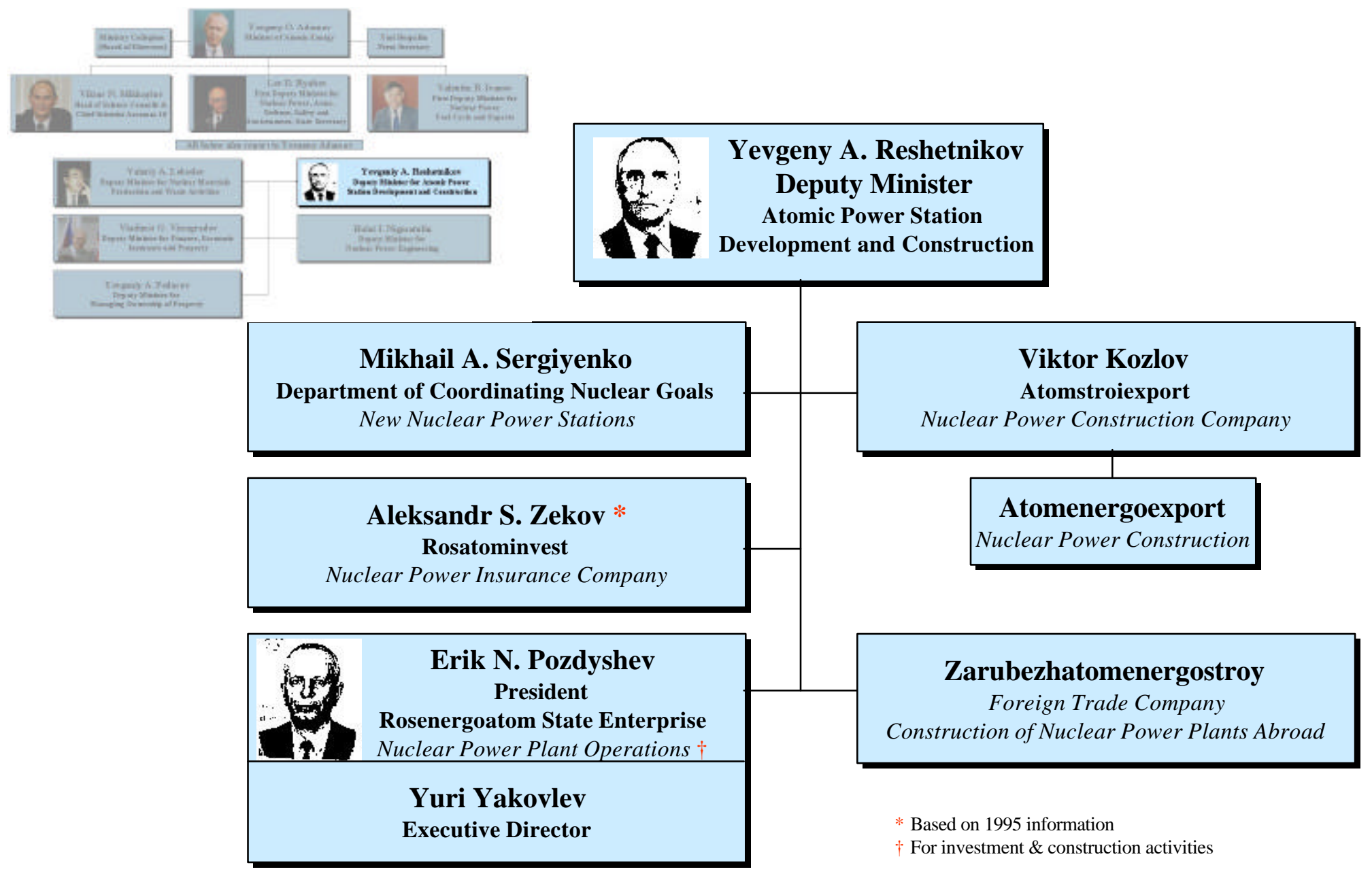




\section{Key Organizations Reporting to the Deputy Minister for Finance, Economic, Insurance, and Property}

Department of Energy
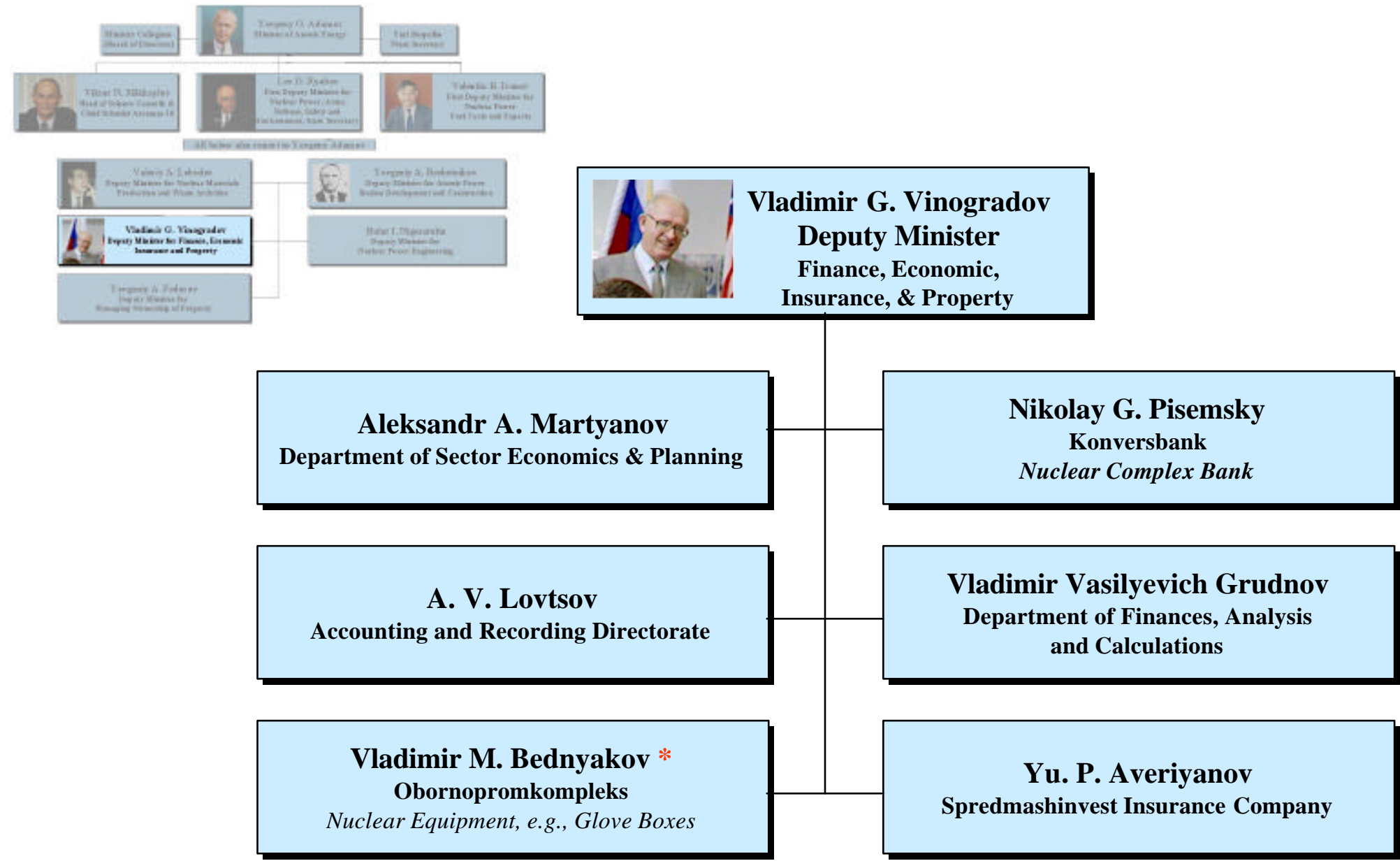

* Based on 1995 information 


\section{Key Organizations Reporting to the Deputy Minister for Nuclear Power Engineering}

Department of Energy

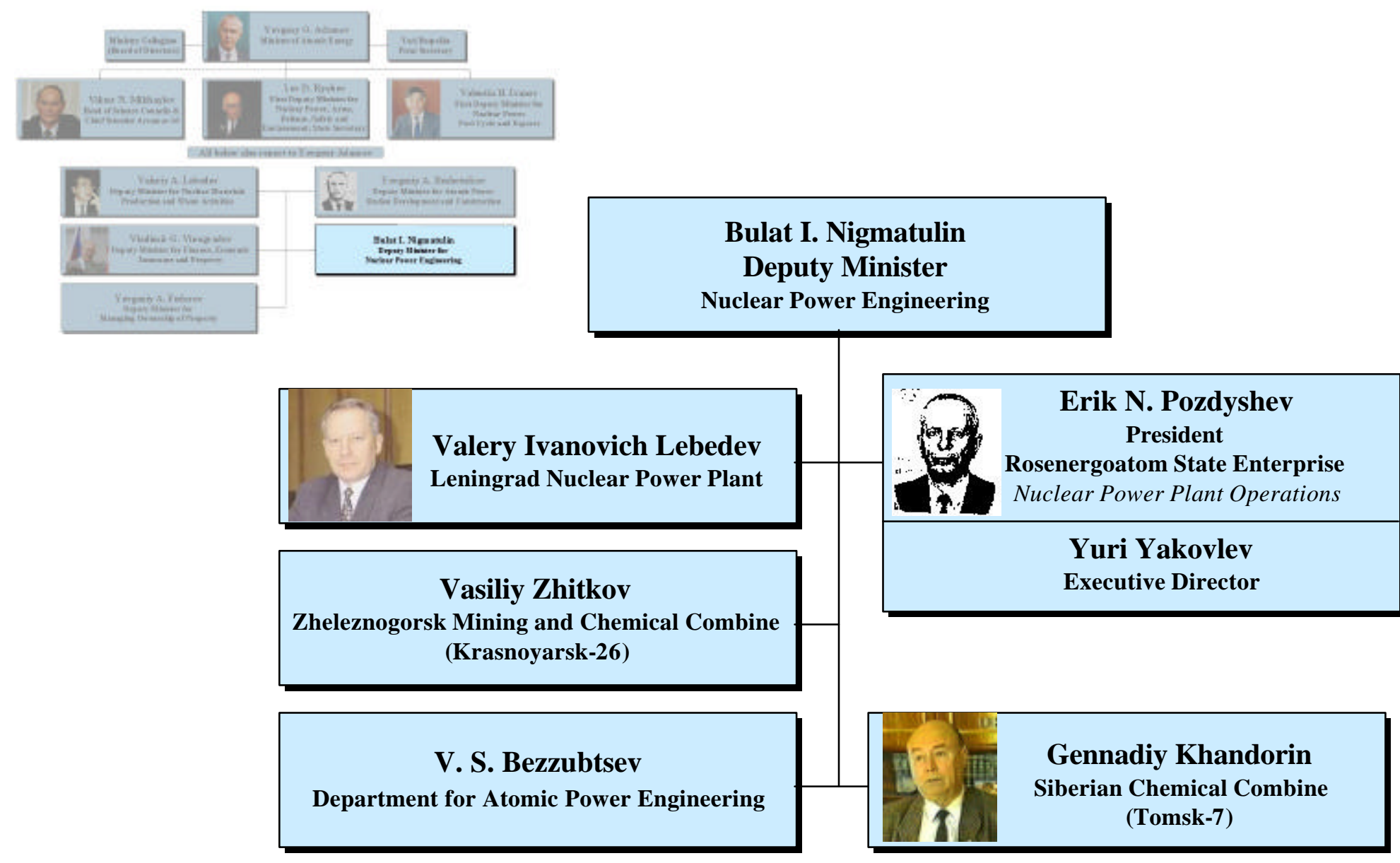




\section{Key Organizations Reporting to the Deputy Minister for Managing Ownership of Property}

Department of Energy
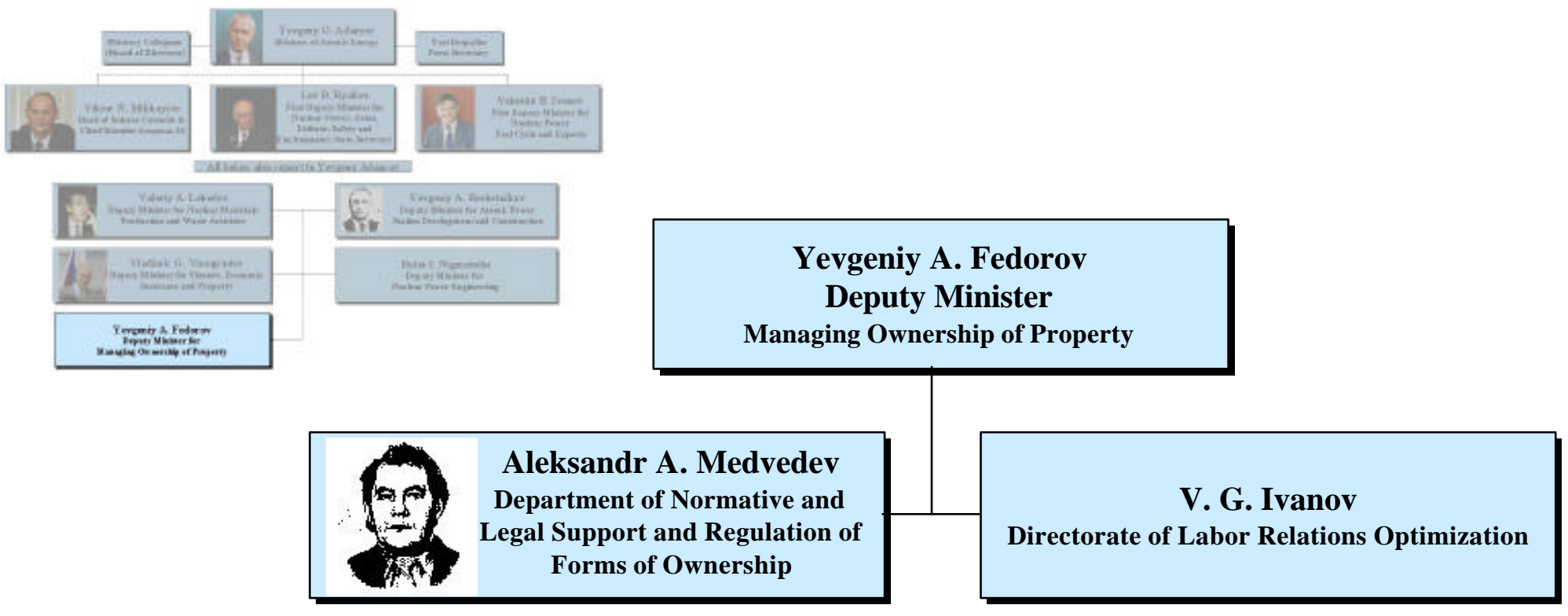